Article

\title{
Investment Model of Agricultural Biogas Plants for Individual Farms in Poland
}

\author{
Kamila Klimek ${ }^{1}\left(\mathbb{D}\right.$, Magdalena Kapłan ${ }^{2}$, Serhiy Syrotyuk ${ }^{3}{ }^{\mathbb{D}}$, Nikolay Bakach ${ }^{4}$, Nikolay Kapustin ${ }^{5}$, \\ Ryszard Konieczny ${ }^{6}$, Jakub Dobrzyński 7,8 ${ }^{(D)}$, Kinga Borek 7,9 (D), Dorota Anders 7,10, Barbara Dybek 7,10, \\ Agnieszka Karwacka ${ }^{7,10}$ and Grzegorz Wałowski ${ }^{7,10, *(D)}$
}

1 Department of Applied Mathematics and Computer Science, University of Life Sciences in Lublin, 20-033 Lublin, Poland; kamila.klimek@up.lublin.pl

2 Department of Pomology, Nursery and Enology, University of Life Sciences in Lublin, 20-033 Lublin, Poland; magdalena.kaplan@up.lublin.pl

3 Department of Energy, Lviv National Agrarian University, 1 V. Velykoho Street, 80381 Lviv-Dubliany, Ukraine; ssyr@ukr.net

4 Deputy Director General for Scientific Work, Republican Unitary Enterprise "Scientific and Practical Center of the National Academy of Sciences of Belarus for Agricultural Mechanization", Knorina 1 Street, 220049 Minsk, Belarus; bakachng@yandex.by

5 Laboratory of Using Fuel and Energy Resources, Republican Unitary Enterprise "Scientific and Practical Center of the National Academy of Sciences of Belarus for Agricultural Mechanization", Knorina 1 Street, 220049 Minsk, Belarus; npcter@yandex.ru

6 Department of Technology, Institute of Energy and Technical Safety, Jacob of Paradyz University, 52 Chopina Street, 66-400 Gorzow Wielkopolski, Poland; rkonieczny@ajp.edu.pl

check for updates

Citation: Klimek, K.; Kapłan, M.; Syrotyuk, S.; Bakach, N.; Kapustin, N.; Konieczny, R.; Dobrzyński, J.;

Borek, K.; Anders, D.; Dybek, B.; et al. Investment Model of Agricultural Biogas Plants for Individual Farms in Poland. Energies 2021, 14, 7375. https://doi.org/10.3390/en14217375

Academic Editors: Sang-Eun Oh, Attilio Converti and Idiano D'Adamo

Received: 26 August 2021

Accepted: 2 November 2021

Published: 5 November 2021

Publisher's Note: MDPI stays neutral with regard to jurisdictional claims in published maps and institutional affiliations.
7 Institute of Technology and Life Sciences-National Research Institute, Falenty, 3 Hrabska Avenue, 05-090 Pruszków, Poland; j.dobrzynski@itp.edu.pl (J.D.); k.borek@itp.edu.pl (K.B.);

d.anders@itp.edu.pl (D.A.); b.dybek@itp.edu.pl (B.D.); a.karwacka@itp.edu.pl (A.K.)

8 Department of Grassland Farming, 3 Hrabska Avenue, 05-090 Pruszków, Poland

9 Department of Rural Technical Infrastructure Systems, 3 Hrabska Avenue, 05-090 Pruszków, Poland

10 Department of Renewable Energy, 67 Biskupinska Street, 60-463 Poznan, Poland

* Correspondence: g.walowski@itp.edu.pl

\begin{abstract}
The main idea of a circular economy (CE) is to separate economic growth from resource consumption and environmental impacts. The characteristic approach of a CE assumes the minimisation of the amount of waste generated at the design level and, as a standard, includes innovations throughout the value chain. From an agricultural point of view, agricultural biogas plants are particularly important because they enable the management of all waste biomass and its conversion into useful energy and agricultural fertiliser. This paper presents methods for assessing the economic effectiveness of an investment in an agricultural biogas plant. The research goal was to develop a financial model. The authors of this study used available examples of the profitability of commercial ventures. We considered the investment aspects of agricultural biogas plants. Exemplary solutions are discussed, allowing the reader to become acquainted with various methods and proposals for thus far estimated investments. It may seem chaotic, but this is how the biogas market is characterised in the context of the implementation of biogas projects. Guidance is given regarding how to understand investing in this sensitive private farming sector. It is admirable that the renewable energy market has been systematised, and we hypothesise that it is necessary to develop an investment model in Polish conditions.
\end{abstract}

Keywords: circular economy; investment; assessment methods; profitability; production; agricultural biogas

\section{Introduction}

Since the industrial revolution, the world economy [1] has been based on the assumption that resources are widely available, easy to obtain, and cheap to dispose of [2]. Such a 
model has placed a lot of pressure on the environment, as it is characterised by the high consumption of raw materials, much waste during production, and that waste's disposal [3]. Therefore, such models are not environmentally sustainable. In particular, the growing awareness that natural resources are finite had led to the development and implementation of new models of the circular economy (CE) that are able to manage existing resources in a continuous cycle, thus ensuring the efficient use of these resources [4]. Therefore, the European Commission argues a CE may be able to provide economic benefits to companies, in addition to environmental benefits, and widely recommends its adoption [2].

Solid municipal waste management (SMWM) [5] continues to be a major challenge for all European Community countries and is an important element in the transition to a CE [6]. In the case of SMWM, an important aspect of achieving CE goals is the plan to reduce landfill weight and increase the proportion of waste that can be returned to the system through material and organic recycling [7]. In the SMWM management system, the sources of generated biowaste are mainly households and business operators [8]. Literature data indicate that the proportion of organic solid municipal solid waste fraction (OSMSWF) ranges from 30 to $40 \%$ on average [9]. A key factor affecting the further utilisation of biowaste is its quality - especially the contamination of the collected material [10]. Biowaste is not only important from the point of view of waste management but also a recognised source of green energy [11]. It can also be successfully used in biofuel production as a substitute for traditional fossil fuels [12]. The technological properties of biowaste are crucial for its further use on an industrial scale [13]. The literature has shown that there is a strong need to convert biowaste into bioenergy technologies (including biogas production) [14]. When planning the development of OSMSWF-processing technology, the global transformation of industry should also be considered [15]. In this context, new solutions should be sought, including the introduction of new business models [16]. These will be inseparably connected, among other things, to the intensive development of selective collection systems [17].

The concept of a CE, introduced by Pearce and Turner [18] in the 1990s is still not at the centre of mainstream management practices despite gaining popularity in academic circles [19]. One reason is the difficulty to convince investors about the sustainable economic efficiency of the undertakings that result from both relatively modest historical experience and the sensitivity of solutions in this area to administrative regulations. Although there is growing ethical pressure to introduce processes other than linear cattle to waste-processing models (i.e., from raw material to waste), the dominant economic evaluation model, focused on short-term rates of return, still makes it difficult to replace the assessment of economic efficiency with broader ecological and economic approaches. The difficulty of convincing investors to extend the capital commitment criteria beyond economic efficiency based on current market prices is evidenced by comparisons of stock exchange indices, which do not clearly reveal the advantage of valuations of enterprises declaring sustainable development compared to enterprises traditionally oriented to the market [20]. The idea of an enterprise that reconciles economic growth with respect for environmental and social values is gradually entering the mainstream, which is manifested by, e.g., new business models including CE models. The main idea of a CE is to separate economic growth from resource consumption and environmental impacts, i.e., to replace the linear business model from raw material to waste with a model in which the final product used (after the longest possible use period) becomes a raw material to a greater or lesser extent. However, in order for this concept to become a business model, it needs to prove its economic efficiency [21]. $\mathrm{A} C E$ is based on four fundamental principles relating to the treatment of the product. In order of importance, these are [22]:

- Extension of the product's life (maintenance) thanks to its design and manufacture in a way that guarantees durability and high quality while maintaining its properties in the long term.

- $\quad$ Multiple uses of the product (redistribution) made possible thanks to its repair and the restoration of its functional characteristics to the maximum extent. 
- $\quad$ Product reconstruction (remanufacturing), i.e., carrying out appropriate processing steps ensuring the return to the original properties with a guarantee for the new owner.

- $\quad$ Product recycling at the end of its effective use period by separating the parts and reusing the recovered materials.

The need to reconcile economic efficiency while considering the physical constraints resulting from recycling is a major difficulty in designing circular business models for companies. The concept of a CE is easier to analyse and implement at the macro- and mesoeconomic levels when it comes to the economic system as a whole. Such a level allows for the extension of the economic account with social costs, which are often beyond the area of influence on the company's decisions. Additionally, at the macro and meso levels, administrative decisions that make it possible to achieve goals that are difficult to achieve through the market mechanism are of greater importance. Business models relate to the microeconomic approach and therefore require the appropriate adaptation of the goals and methods of a CE to the level of the enterprise, i.e., combining the business goal (increase in the company's value, liquidity, and market share) with the criteria of CE (3R-reduce, reuse, and recycle) [23]. When designing CE business models, one should refer to their basic dimensions [24]:

- Define the value proposed to clients.

- $\quad$ Define the way of creating this value.

- Define resources and conditions for achieving the company's goal.

- Consider the generation of financial effects in the company.

Taking the abovementioned universal features into account, a business model relating to a circular economy can be defined as a concept describing the value proposed for current and future customers and other stakeholders, the way in which the company intends to create and transfer it, and the methods of financing generating income for the company; all this is to be achieved while using environmental resources in a sustainable and 3R way. This definition is based on the sustainable business model presented by Schaltegger et al. [24]. On this occasion, we must mention the growing popularity of the concept of sustainable business models, one feature of which is a harmonious relationship between economic, environmental, and social aspects within a business project [25]. The relationships between the $\mathrm{CE}$ and sustainable business models require further analysis, although it seems that the concept of a sustainable business model is broader and also includes circular models.

The new economy model, which is a CE, is based on the assumption that the value of products, materials, and resources is to be kept in the economy for as long as possible in order to keep waste generation to a minimum. In this concept, raw materials are recycled many times, often from one industry to another. In other words, this concept is based on closing the product life cycle and switching from the linear economy model (raw material acquisition-production-use-waste disposal) to the circular model (production-use-use of waste as a raw material in the next production cycle). A schematic comparison of two economy systems - traditional (linear) and environmentally friendly (circular) was presented in [26].

According to the definition of the European Commission [2], "A circular economy is a development strategy that assumes economic growth without increasing resource consumption, profoundly transforming production chains and consumption habits, and transforming industrial systems at the system level. It is based on technological, social and organisational innovation." The Polish Institute of Eco-Development defines a CE as a set of principles concerning production and services that are radically different from the so-called a linear model that is dominant in today's economy, which is based on continuous growth and the ever-increasing consumption of raw materials. A CE goes further than using ecoefficient resources and technologies in single actions. Moving to a CE requires changes at every link in the value chain, including product design, new business and market models, new ways to turn waste into resources, and new consumer behaviour. In December 2015, the European Commission communication "Closing the loop-action plan of the European 
Union (EU) for the circular economy" proposed that all EU member states to switch from the linear economy model to the CE model [2]. A CE, the Commission assures, will also contribute to the emergence of new, more resource-efficient production and consumption patterns, as well as the creation of 2 million new jobs across the EU by 2030. With existing infrastructure, business models, and technology, economies remain stuck to the linear model. Consumers' schematic habits may also comprise an obstacle to new products and services. The characteristic approach of a CE assumes the minimisation of the amount of waste generated at the design level, and, by default, it includes innovations in the entire value chain - not only solutions at the end of the product life cycle [26].

In agriculture, a CE primarily means:

- Preservation and enhancement of natural capital.

- Optimisation (not maximisation) of natural resource efficiency.

- Promotion of the efficiency of waste use and the elimination of harmful practices.

- Promotion of interaction between people, efficient use of resources, and optimal management of unavoidable waste.

- Promotion of economic instruments to discourage landfilling.

- Specific actions to promote the re-use of products (promotion of the "end product in one industry-input material in another industry" model).

- Economic incentives for producers to introduce greener technologies.

The ideal response to the above-described new challenges and trends is biogas, which is a renewable fuel with favourable characteristics and parameters that enable its wide use in practically every economic area. In the field of electricity production, biogas generation sources are characterised by the stability and controllability of energy production similar to traditional sources powered by fossil fuels. Biogas is locally produced fuel, most often from raw materials obtained in the vicinity, and it is an energy carrier that leaves a relatively small carbon footprint; in the case of some raw materials (e.g., biogas from wet manure) or technology (storage of digestate in closed tanks and methane capture), it even leaves a negative footprint. Both the type of raw material (in particular, the use of waste and residues from the production of goods in other sectors of the economy-e.g., agriculture, agri-food industry, or forestry-is rewarded) and the possibility of local obtainment (and no need for transport over long distances) have significant impacts on reducing the carbon footprint. The promotion of biogas and biomethane therefore fits in with the trends in promoting a $\mathrm{CE}$ - what would otherwise be a waste or a production residue that is negligible in terms of economic attractiveness is a raw material that can be recycled for the biogas sector. This approach allows for the creation of new markets and, consequently, new jobs in the medium and long term. Moreover, biogas can be used as an ecologically clean means of storing energy. The use of power-to-gas technology to store excess energy produced with non-controllable renewable energy sources (e.g., generated by photovoltaic installations on exceptionally sunny days or by wind farms in windy weather) is becoming more and more popular. Using this excess electricity to produce biogas, which could then, at times of increased demand, be turned back into it again is a way of storing it. It should be emphasised that this method of energy storage does not generate hazardous toxic waste that may be generated, for example, after the end of the life cycle of chemical batteries [27]

The RED II directive, which entered into force on 24 December 2018, is now the main piece of legislation regulating the renewable energy market in the EU. The overarching goal of the RED II Directive is to achieve the EU target of increasing the share of renewable energy in the EU's energy mix to at least $32 \%$ by 2030 . The RED II Directive indicates the increasing importance of biogas in the form of biomethane, mainly in transport. In this context, it has a special role to play in light of Art. 25 of the Directive, which requires member states to require fuel suppliers to ensure at least $14 \%$ share of renewable energy in final energy consumption in the transport sector by 2030. Biofuels, including advanced biofuels and biogas produced from raw materials listed in Annex IX of the RED II Directive, and renewable electricity in the transport sector will contribute to reducing carbon dioxide emissions and thus reduce the emissions of the EU transport sector. It is equally important 
that biogas technologies are cost-effective technologies and allow for the diversification of energy sources in the transport sector while supporting innovation, increasing employment in the EU economy, and reducing dependence on the import of energy and raw materials for its production. RED II requires member states to require that fuel suppliers ensure a minimum share of advanced biofuels and certain biogases. Advanced biofuels and biogases produced from raw materials listed in Annex IX as a share of final energy consumption in the transport sector are expected to comprise at least $0.2 \%$ in 2022 , at least $1 \%$ in 2025 , and at least $3.5 \%$ in 2030. Annex IX suggests the use of biomass fraction from mixed municipal waste, household biowaste-including straw or manure and sewage sludge, which are used for the production of biogas or biomethane-in the practical implementation of the national sub-target for advanced biofuels. This is significant because, according to the analyses carried out by the Ministry of State Assets on the occasion of the construction of the "National Energy and Climate Plan for 2021-2030", "in Poland this target (set for 2020 at $0.5 \%$ ) it is not feasible due to the limited access to technologies processing lignocellulosic raw materials and algae and the limited supply of waste materials". It is also important for market development to specify that in the RED II Directive, the guarantee of origin system may also cover gas (including biogas) [27].

Biogas, the main component of which is biomethane, is produced from waste biomass in the methane fermentation process [26]. From the agricultural point of view, agricultural biogas plants are particularly important because they enable the management of all waste biomass and its conversion into useful energy and agricultural fertiliser, as well as solving the problem of methane emissions released from biomass. In addition, local agricultural biogas plants, which deliver surplus energy to the grid or methane to the gas grid, may become important links in a decentralised energy production system [28]. In recent years, the number of installations for the production of agricultural biogas in Poland has significantly increased, which means that the market in Poland, under certain conditions, allows this costly investment to bring profits to its investor. Numerous analyses have shown that this investment is sensitive to changes in market conditions, but in the long run, it brings positive value to the economic balance due to high investment costs; therefore, financial support is important at the stage of building a biogas plant. This support largely allows one to shorten the payback period and thus increase the tendency of future investors to build biogas plants. The second important issue is the price of the mandatory purchase of energy from agricultural biogas plants. Unfortunately, investments in biogas plants are still subject to high risks. Analyses of the profitability of biogas plants have shown that without the financial support (co-financing) of at least part of the investment at the construction stage, the investment becomes unprofitable in a assumed period of time (such as 12 years), and the same situation may result from a decrease in revenues from energy sales.

The introduction of an upgrading unit into an existing anaerobic digestion plant to convert biogas to biomethane can have a strong impact on the overall energy balance of the systems. The amount of produced biomethane can be optimised in terms of energy, environment, and economics [29]. Anaerobic digestion systems produce clean energy from organic waste [30], promote the diffusion of the economic cycle [31], and provide sanitation services [32]. The biogas produced in an anaerobic digestion system is burned in a cogeneration node to generate heat for the digestion process and electricity [33]. Cogeneration is only viable if the end user is within a short transmission distance [34], and the heat from cogeneration feeds the drying system, thus reducing the cost of transporting and disposing of the digestate [35]. Currently used government subsidies are used to promote the production of biomethane injected into the natural gas grid [36]. Biomethane is mainly composed of methane (more than 97\%) [37] and is desirable in the transportation sector as either a compressed gas [38] or in the liquid state [39]. The potential for biomethane production is currently focused on maximizing production by improving the fermenter diet [40] and forecasting production [41]. When producing biomethane, the effect of the upgrading system on the energy balance of the plant created by conversion [42] and the 
optimal size of the cogeneration unit [43] are important. Therefore, an appropriate selection of the combined heat and power (CHP) is required.

Biogas plants fed only with animal effluent provide very interesting energy and financial results [44]. The achievable gain from organic matter available in farm wastewater can be up to about $60 \%$. Variability in the amount of available biomass can be a problem resulting in higher self-consumption due to lower yields per unit of volatile solids and dry matter concentration. It should be stated that the supply chain of biogas from animal wastewater has some special characteristics that make it attractive to the agricultural world [45].

Biogas plants operating on organic waste are at the heart of the reliable, low-carbon, multi-energy systems of the future [46]. As cogeneration units, biogas plants significantly contribute to further interconnection of future energy systems, acting as intermediaries, especially in the thermal domain [47]. Due to the increased emphasis on hydrogen as an important and promising energy carrier for the low-carbon industry and mobility sectors [48], biogas plants also represent convincing choices of investment locations. Biogas plants can support the transformation towards sustainable and renewable energy systems, and they can provide network balancing services to complement the volatile generation from renewable energy sources while supplying electricity and heat vectors [49]. From an operational point of view, Dotzauer et al. [50] tested performance indicators for elastic, demand-driven biogas production to determine the biogas characteristics of plant elasticity. Mauky et al. [51] investigated the effect of flexible feeding strategies and substrate types on biogas plant flexibility and process stability. The authors of [52] presented a modelpredictive controller for deriving power strategies for demand-driven electricity production. The biogas plants envisaged in the modular structure would contribute to the orientation of the output to integrated energy systems. Korberg et al. [53] analysed biogas and biogas fuels in a 100\% renewable energy system in the Danish context. The authors concluded that from an energy efficiency point of view, the use of raw biogas without multiple conversion steps is advantageous in comparison to other biogas-derived fuels for electricity and heat generation. The roles of biomethane and electrofuels will largely depend on the specificity of the application and potential alternatives, e.g., direct electrification in the transport sector.

Agricultural biogas plants are now becoming stable sources of electricity and, increasingly, heat production [54]. They comprise one of the development technologies of biomass conversion from renewable energy sources, so it is necessary to conduct in-depth analyses at the level of investment decisions [55].

\section{Aspects of Investment Decision Making in the Development of Biogas Technology}

\subsection{Development of a Biogas Plant}

The most technically advanced biogas plants in the world have been constructed in Germany and Denmark for 15 years. In Germany, the Act on Renewable Energy Sources (RES) has been in force since 2000 [56] and requires companies from the energy sector to supply energy produced from RES to the electricity grid for 20 years at guaranteed tariffs [57]. In 2004 and 2009, amendments to the RES Act were introduced, thanks to which it was established that the cultivation of energy crops was to be purposefully used in the process of anaerobic digestion [58]. In the years 2000-2012, the German economy showed that the number of biogas plants [59] increased from 1050 to 8292; biogas production is currently at the level of about $50 \%$ of the production of the EU [60]. In countries such as Austria, Switzerland, and Sweden, the development of biogas plants remains at a slightly lower level [61]. In other countries such as Spain, Italy, Belgium, and the Netherlands, the first modern biogas plants have been in operation for several years and others are under construction. A number of other European countries are interested in developing biogas plants, especially Poland, Hungary, Lithuania, England, and Ireland [62]. Increasing amounts of organic waste comprise is a huge problem in the EU [63] that requires special treatment [64]. It was observed that in the period of 2009-2016, the number of biogas 
plants in the EU steadily increased from 6227 to 17,662 [65]. As of 2020. Europe dominated the biogas market and was the largest biogas producer, with about 18,943 biogas plants. According to the European Biogas Association (EBA), biogas production in Europe is expected to reach 98 billion cubic meters $(\mathrm{bcm})$ of biomethane by 2050, an increase of $4800 \%$ of current production levels. The plan to increase biogas production is expected to attract investment in biogas plant construction, which is expected to support biogas plant development in the near future [66]. In the USA during 2002-2016, 23 complete biogas projects were implemented with the support of the National Institute of Food and Agriculture; two projects have been implemented since 2017. The aim is to use highly efficient engineering systems capable of converting concentrated waste streams into fertilisers, energy, and clean water [67].

Biogas plants are currently a technological development on two continents: Asia and Europe. In China, there are several million small, very simple biogas installations powered by agri-food waste that are self-made by simple methods, cheap to build, and effective at farms. Chinese farmers use the biogas produced in this way to cook and light their homes for their own needs. There are around a million similar biogas plants in India, as well as some in Japan and South Korea, that are implemented in a modern way based on European biogas technologies.

The EU defines biomass very broadly, for which it accepts biodegradable product fractions, waste, and residues of the agricultural industry (including plant and animal substances), forestry, and related industries, as well as biodegradable fractions of industrial and municipal waste. Moreover, in the last few decades, the problem of environmental pollution has gained particular importance in industrialised countries. This is related to the intensification of agricultural and livestock production and the degree of processing of agri-food products. There has been a significant increase in the amount of waste and organic pollutants that arise in agriculture and related industries.

The national action plan for Poland covering energy from renewable sources assumed that there would be $980 \mathrm{MW}$ of installed electricity capacity in biogas plants in Poland by 2020. The plans also assumed that there would be 2000 jobs by 2023 . Such assumptions are impossible to implement in the current economic conditions. In less than 3 years, installations with a capacity of $750 \mathrm{MW}$ would have to be built, i.e., a total of 750-800 agricultural biogas plants. These numbers are unattainable in such a short time. At the end of 2019, 310 biogas plants were operating in Poland, including only 120 agricultural biogas plants with a total electrical capacity of 101.3 MW.

Currently, $80 \%$ of biogas plants in the world operate in Germany, including the two largest capacities of $20 \mathrm{MW}$ each, both of which generate demand for the substrate collected from an area of 12 thousand hectares.

An analysis of the literature showed that by the end of 2012, the increase in the construction of biogas plants was due to generous government subsidies that translated into energy production. In fact, the most common rated electric power of a power plant is $1 \mathrm{MW}$, and the construction cost ranges from 4.2 to 4.8 million-65\% for biological devices and the rest for a power unit. Various substrates including energy crops, manure, and waste water are used in the fermentation process, while manure causes operational problems for the plant [68]. Note that these Organic Rankine Cycles (ORCs) must be designed using measurement data, not nameplates. This is because each engine is calibrated on the basis of the biogas composition, which is in turn influenced by the biomass input (substrate). Therefore, additional feed-in tariffs for electricity production should be introduced in order to improve the sustainability of the biogas sector in favour of waste heat recovery units [69]. In 1960s Poland, industrial farms developed [70], with 2000 fattening pig farms by the end of the decade [71]. In 2008, the Helsinki Commission (HELCOM) [72] recognised large farms as point sources of agricultural pollution. Cattle farms with stocking equivalent to $400 \mathrm{AU}$ animal units are also considered industrial farms. In Poland, 752 large-scale poultry farms, 606 cattle farms, and 126 pig farms have been registered [73]. Industrial-type farms are characterised by excessive production and a uniform cyclical 
supply of a product of appropriate quality, but these effects are achieved at the cost of excessive energy consumption and the unacceptable living conditions of animals. The most disadvantageous condition from the point of view of environmental protection is breeding in a system without a cage, which is associated with the formation of huge amounts of liquid manure [74]. The profitability of investing in biogas plants is determined by the possibility of selling or using thermal energy obtained from the conversion of slurry in cogeneration installations. In our opinion, it is most reasonable to promote solutions based on individual farms in which farmers show willingness to engage and cooperate with biogas plants at an optimal power of $10 \mathrm{~kW}$.

\subsection{Slurry}

Slurry is problematic during storage and operation, posing an environmental threat to industrial animal husbandry [70]. Cattle, pig and poultry slurry are distinguished, with the last type being discharged from farms in a dry state in the so-called form of litter. Slurry has also been classified according to its admixture content (e.g., slurry, on-farm, or external wastewater). In this case, a distinction is made between full (without any admixtures) or incomplete (mixed with at least one of the abovementioned admixtures) [75]. Slurry is a liquid product [76]; it is a mixture of animal excrements with the addition of technological water, as well as feed and watering residues. During the year, cattle breeding and pig production produce slurry in the ranges of $7.5-21 \mathrm{~m}^{3}$ and $1.2-6.0 \mathrm{~m}^{3}$, respectively [77]. With one high conversion factor, the amount of slurry produced by a fattening pig has been calculated as $45 \mathrm{~kg}$ per day [78], which provides $20 \mathrm{~m}^{3}$ of slurry per $1 \mathrm{AU}$ in 1 year [79]. In practice, it is assumed that 1 ton of slurry has a volume of $1 \mathrm{~m}^{3}$ [77], with an average dry matter content [70] of $8.5 \%$ in cattle slurry and $5.65 \%$ in pig slurry. Nitrogen (50\% water-soluble and $40 \%$ ammonium nitrogen) in a slurry is formed via urea [80] in organic and mineral combinations. On the other hand, the C:N ratio in a slurry is on average 6.8 [81], and the $\mathrm{pH}$ of a slurry is alkaline and stable at 7.1.

\subsection{Investment Outlays}

The construction of a biogas-upgrading installation to the parameters of natural gas involves significant expenditure. The total amount of capital expenditure and annual operating costs primarily depends on the size of the installation and the type of technology used. Based on an analysis of currently operating installations of this type in Europe, it can be estimated that the average investment costs range from EUR 0.5 to 0.8 million in the case of a biogas installation producing $250 \mathrm{Nm}^{3}$ of biogas / $\mathrm{h}$ - equivalent to $500 \mathrm{~kW}_{\mathrm{el}}$ - and up to 1.2-1.5 million EUR for an installation generating $1.000 \mathrm{Nm}^{3} / \mathrm{h}$ - equivalent to $2 \mathrm{MW}_{\mathrm{el}}$ ) [82] The target group, i.e., the group with access to the substrate (pig slurry), may have problems with its disposal for the optimal livestock of 1200-2400 piglets or fattening pigs for one farm. Previous foreign and domestic experiences have shown that the agricultural biogas plant sector is governed by the principles of economies of scale, i.e., unit investment outlays increase or decrease along with changes in the efficiency of the installation. Currently, it is difficult to indicate the technical and economic criteria [83] of the division of micro-biogas plants with less than $100 \mathrm{~kW}_{\mathrm{el}}$ of electric power, small biogas plants with $100-500 \mathrm{~kW}_{\mathrm{el}}$ of electric power, medium biogas plants with $500-1000 \mathrm{~kW}_{\mathrm{el}}$ of electric power, and large biogas plants with more than $1000 \mathrm{~kW}_{\mathrm{el}}$ of electric power because there has been no larger statistical sampling of investments carried out in Poland. The general breakdown of the individual categories of expenditure into sub-components depends on the equipment of the biogas plant's process line, but there are some significant and recurring categories of expenditure. In analysed biogas plants, two basic elements have been shown to have the largest shares: the construction of fermentation chambers and the purchase of cogeneration units. Each of these elements accounts for approximately $20 \%$ of capital expenditure [83]. The structure of biogas plant expenditure is presented in Table 1 . The selection of technological options has a significant impact on the percentage share of a particular category, which can significantly shift the percentage share of investment outlays. 
Table 1. Structure of investment categories for a silage-based biogas plant and maize slurry with a capacity of $0.86 \mathrm{MW}_{\mathrm{el}}$ [83].

\begin{tabular}{lc}
\hline Categories & $\begin{array}{c}\text { Average Share } \\
\%\end{array}$ \\
\hline Fermentation tank & 16 \\
CHP & 17 \\
Storage and pre-treatment of substrates & 12 \\
Construction and assembly works & 13 \\
Storage of the fermented pulp & 6 \\
Power and measuring systems & 8 \\
Heating system & 3 \\
Means of transport & 2 \\
Water and sewage/gas installations & 7 \\
Other & 16 \\
\hline
\end{tabular}

\subsection{Investment Profitability}

Information on the preparation of an investment profitability analysis will allow for the development of a model to support the decision-making process regarding the construction of a biogas plant [55]. Investors have the greatest confidence in methods for assessing the economic efficiency of investments such as net present value (NPV), internal rate of return (IRR), simple payback time (SPBT), discounted payback period (DPP), and profitability index (PI).

NPV is used in capital budgeting and investment planning to analyse the profitability of a planned investment or project. NPV is the result of calculations to find the present value of a future stream of payments [84]. IRR is used to estimate the profitability of potential investments; it is the discount rate that makes NPV $=0$ in a discounted cash flow analysis. In general, the higher the IRR, the more desirable an investment [85]. NPV and IRR allow for the assessment of individual investment projects based on a discounted cash flow analysis. They are applied at a fixed discount rate over the considered period [86].

The NPV rate is the difference between the discounted cash flows and the initial expenditure, as expressed by the Equation (1):

$$
\mathrm{NPV}=\sum_{t=1}^{n} \frac{C F_{t}}{(1+r)^{t}}-I_{0}
$$

where NPV is net present value, $C F_{t}$ is cash flows in the period $t, r$ is discount rate, $I_{0}$ is initial expenditure, and $t$ is subsequent periods (years) of operation of the biogas plant.

IRR indicates an average return of capital involved in an investment over the lifetime of the investment. Given that 1 EUR converts to PLN 4.53 (14 May 2021, 05:51 UTC), if EUR 1 of total capital involved in a given investment yields a net benefit of EUR 0.04 (IRR $=20 \%)$, the cost at which capital can be raised to finance the investment cannot exceed $20 \%$ in order for the investment to be profitable [83].

SPBT denotes the time needed to recover the capital expenditure incurred for a project. It determines the moment when the gross benefit offsets the expenditure incurred [87]. The most common static criterion for assessing economic efficiency is the simple payback time of SPBT. It is defined as the time needed to recover the investment outlays incurred for the implementation of a given project. It is counted from the moment of the investment is launched to the moment when the sum of gross benefits obtained as a result of the investment realisation balances the incurred expenditures [88].

DPP is a modified version of the payback period that considers the time value of money (i.e., "break-even") or the situation where the net cash flow generated covers the initial cost of the project while considering the payback period (PBD) for the feasibility of a specific project [89]. PI, referred to as value investment ratio (VIR) or profit investment ratio (PIR), denotes the cost/benefit ratio of the proposed project. It is calculated as the 
ratio of the present value of future expected cash flows to the initial amount invested in the project. The higher the PI, the more attractive the design [90].

Another investment tool is real options analysis (ROA) [91], which covers a wide range of cost-benefit analysis techniques and was used for the valuation of renewable energy by Angelika Menegaki et al. in 2008 [92]. Subsequently, ROA began to be refined and used, inter alia, in the energy sector for investment evaluation [93]. At present, ROA is considered the most appropriate tool for investment valuation due to the nature of research [94] that has led to a versatility of applications. At different stages of an investment project, ROA for mining can be defined by:

- Exploration.

- Development.

- Extraction.

- Remediation [95].

However, for renewable energy projects, there are two stages:

- Planning.

- Operational [96].

The most frequently identified option is a deferment of investment or a time option that consequently results in some of this uncertainty being resolved. The deferral option is modelled and allows for a comparison of different time alternatives by using binomial trees [97] or incorporating dynamic programming into models formulated with partial differential equations [98]. A combination of dynamic programming and other methods is used to incorporate the choice of technology [99] or the choice of performance [100] into an optimal investment design. The second most studied investment option reflects the concept of the entire investment project as a real option [101]. For this option, solutions using binomial, scenario, or decision trees are proposed as the most convenient method of modelling various $R \& D$ development scenarios [102]. The ability to switch inputs or outputs is characteristic of bioenergy projects, the operation of which can be adapted to changing prices of inputs or outputs using Monte Carlo simulation [103]. For ROA valuation, the inclusion of the fuzzy set theory is used to capture uncertainty and imprecision. Sheen [104] combined the Black-Scholes [37] method with fuzzy input data, and Kozlova et al. [105] demonstrated the use of an independent fuzzy payment method for the valuation of the ROA of a renewable energy project. The attempts to support ROA valuation with empirical evidence should also be considered; one example is a regression analysis of data from construction permits, which indicated investor activities in accordance with the ROA theory, though the investment rules for one owner may be dictated by traditional NPV analysis [106]. More evidence supporting investors' behaviour according to ROA theory came from the same dataset in later work [107].

\subsection{Purpose and Scope}

The aim of this article was to develop an investment model of an agricultural biogas plant in Polish conditions for individual farms. The analysis of three examples (available in the literature) was included in a study of infrastructure investments (construction and operation) of agricultural biogas plants in Poland under the conditions of individual farms. It should be emphasised that the structure of investment categories was based on biogas plants with a capacity of $0.86 \mathrm{MW}_{\mathrm{el}}$. The relationship of rates was described while considering the impact of the sale price of certificates of origin on NPV and IRR, a constant electricity sale price to the grid, and the impact of the substrate purchase price on NPV and IRR. A financial model based on our own calculations and available literature materials was developed, thus indicating the profitability of biogas plants. By analysing the forecasted cash flows and financial results, it was shown that the financial result may be positive throughout the life of a biogas plant. On this basis, a literature review indicated the need to develop an investment model for a biogas plant that assumes investment profitability, project sensitivity risk, and investment cost flow. 
The authors of this article discussed examples of solutions that allow the reader to grow acquainted with various methods and proposals for so far estimated investments, though they cannot always be applied to individual farms. This research gap, consisting of the lack of a universal or flexible application of the investment model, has created a shortage for potential investors in agricultural biogas plants. It is also a kind of a deterrent to the development of individual renewable energies. Business models (characterised by innovative solutions and reference costs) consisting of the sale of purified biogas (biomethane) to the network have not yet been tested in Polish conditions, although they are known and have been implemented in other EU countries. Along with the development of national regulations, there have been a few attempts to build biogas-upgrading installations to natural gas plants, which are burdened with large investment expenditures (total and annual operating costs) depending on the size of the infrastructure and the type of biogas treatment process used. The lack of technological support from leading research centres in Poland has widened the gap in this area, though capital intensity has played the greatest role. High financial outlays combined with a long payback period may change only when the production of individual components for the construction of biogas plants is carried out on a larger scale in Poland. In the long term, the benefits that a future investor may achieve, especially an individual farm, are not defined. It is necessary to make further attempts and practically develop investment models that will determine the efficient functioning of farms using renewable energy for innovative solutions such as agricultural biogas plants.

\section{Materials and Methods}

The following section provides information on the modelling approach for biogas plants and describes the main relationships needed to estimate the economic indicators. The model was implemented in the environment of individual investments and shows profitability over time.

The exemplary cost of constructing an agricultural biogas plant with a capacity of $1 \mathrm{MW}$ is approximately EUR 2.6-3.3 million [108]. It was assumed that the possible lifetime of a biogas plant is 20 years. A fixed discount rate of $7 \%$ was assumed. The financial risk to a biogas producer results from the volatility of energy prices and certificates of origin. As basic indicators for economic evaluation of investment, the NPVs and IRRs strictly depend on the price of energy certificates of origin-see Figure 1a. If NPV $\geq 0$, then the investment should be accepted, and if NPV $<0$, then the investment should not be conducted. According to current calculations, the price of certificates of origin at the level of approximately 46.36 EUR/MWh is the limit value below which NPV has a negative value, thus proving that the investment is not profitable. IRR is also useful for assessing the profitability of investments; when its value is equal to or higher than the so-called "cap rate", e.g., a real interest-bearing loan, the investment can be considered profitable. The IRR for a $1 \mathrm{MW}$ biogas plant at a price for certificates of origin of $46.36 \mathrm{EUR} / \mathrm{MWh}$ falls below $5 \%$, so it is difficult to expect the profitability of such an investment at current commercial credit rates. The improvement of economic rates will be ensured by obtaining preferential credit or subsidies for investments.

The economic rates of biogas plants are significantly influenced by the purchase cost of substrates-see Figure 1b. At current prices for energy sale and certificates of origin, the price for silage is approximately $18.76 \mathrm{EUR} / \mathrm{Mg}$. The purchase of substrate at a higher price makes the production of energy from biogas no longer profitable. Therefore, it is advisable to seek waste substrates at the lowest possible cost. From the point of view of farmers as suppliers of substrates, there is a risk that the contract is prepared in an incorrect way, maybe too generally, and may depend on the situation of the biogas plant itself. Therefore, it is very important that the contract is written in such a way as to satisfy both parties and that the farmer exactly knows how much and in what form he will be remunerated for each kind of biomass [108]. 


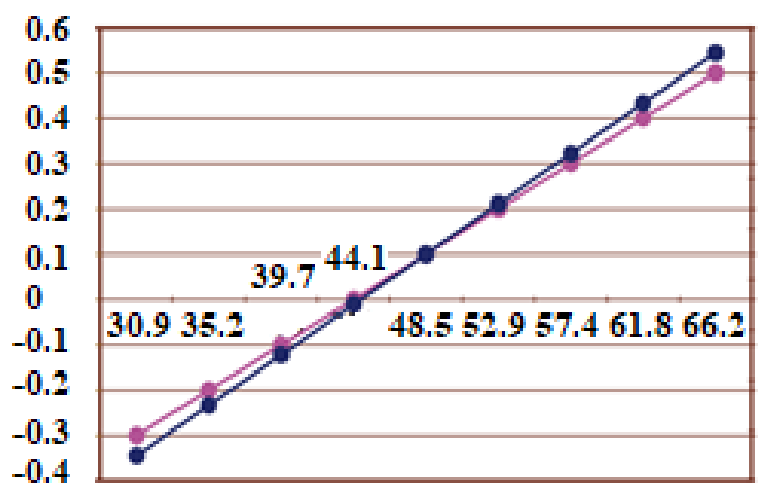

Sale price for certificates of origin [EUR/MWh]

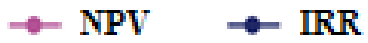

(a)
NPV [million EUR]

IRR [\%]

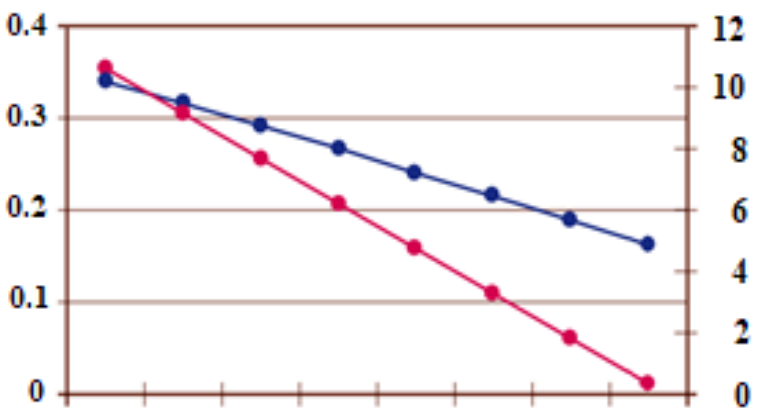

$\begin{array}{llllllll}11.0 & 12.1 & 13.2 & 14.3 & 16.5 & 17.6 & 18.7\end{array}$

Sale price for silage [EUR]

NPV $\rightarrow$ IRR

(b)

Figure 1. Dependencies of rates [108]: (a) impact of the sale price for certificates of origin on NPV and IRR, with a fixed sale price for electricity to the grid; (b) impact of the purchase price for corn silage on NPV and IRR.

On the basis of the aforesaid methods, it was also possible to identify potential risks and predict possible difficulties on the basis of the developed financial model for biogas investments.

Our financial model was developed to provide support for the decision-making process of building a biogas plant. Considering the parameters for assessing its effectiveness, provided that certain economic events occur, the investment was assumed. The examined investment was a completely new activity that is not connected with any enterprise. A special purpose vehicle was established for the construction of a biogas plant and for further operations.

The above examples of the profitability assessment of investments in the infrastructure of agricultural biogas plants in Poland were developed on the basis of the analysis of the literature and collected data (in the form of tabular summaries), which enabled evaluation and analysis in the economic context. The average cost of constructing a biogas plant in Poland, calculated per 1.0 MW, amounts to about 3.3-3.5 million EUR/MW. The financial model (Table 2), based on calculations and available materials, assumed that the construction of the biogas plant from the purchase of land to its commissioning would cost EUR 3.5 million [55]. 
Table 2. Financial model (own elaboration).

\begin{tabular}{|c|c|c|c|c|c|}
\hline Time & Investor & & & \multirow[b]{2}{*}{ Operation of a biogas plant } & \multirow[b]{2}{*}{ VAT } \\
\hline \multirow[b]{2}{*}{2017} & Credit & Grant & $\begin{array}{l}\text { Own } \\
\text { contribution }\end{array}$ & & \\
\hline & $\begin{array}{l}\text { EUR } 0.7 \text { million on preferential } \\
\text { terms ( } 3 \% \text { cost of capital over the } \\
\text { entire loan period). } \\
\text { EUR } 1.58 \text { million } \\
\text { obtained with the assumption of } \\
\text { an interest rate of } 7 \% \text { in the first } \\
\text { period and } 6 \% \text { from the start of } \\
\text { the biogas plant. } \\
\text { Interest repayment starts as soon } \\
\text { as the commitment is made. }\end{array}$ & $\begin{array}{l}\text { EUR } 1.1 \text { million- } \\
\text { decision to grant a subsidy for the } \\
\text { construction of a biogas plant. }\end{array}$ & EUR 0.15 million. & $\begin{array}{l}\text { For the purposes of the calculation, it } \\
\text { was assumed that the biogas plant will } \\
\text { operate } 8000 \mathrm{~h} \text { per year, i.e., } 334 \text { days } \\
\text { ( } 91 \% \text { of the entire year). } \\
\text { As such, there is not much time for } \\
\text { downtime or maintenance work, and } \\
\text { to operate a biogas plant, it is necessary } \\
\text { that at least } 1 \text { person is on site all the } \\
\text { time. Many actions are mechanised, } \\
\text { but in the event of a failure, immediate } \\
\text { response is required. }\end{array}$ & $\begin{array}{l}\text { For the purposes of the } \\
\text { valuation, VAT was } \\
\text { omitted. It was assumed } \\
\text { that during the } \\
\text { investment, the investor } \\
\text { will claim a VAT refund in } \\
\text { every period so it will } \\
\text { become neutral from the } \\
\text { point of view of the } \\
\text { investment assessment. }\end{array}$ \\
\hline 2018 & $\begin{array}{l}\text { Start-up of a biogas plant-the } \\
\text { biogas plant generates } 8000 \mathrm{~h} \text { of } \\
\text { work throughout the year. } \\
\text { The principal in each of the loans } \\
\text { will be repaid from December } \\
2018 \text { over a period of } 10 \text { years. }\end{array}$ & \multirow{2}{*}{$\begin{array}{l}\text { Technology, buildings, equipment and } \\
\text { machinery, infrastructure will be } \\
\text { proportionally financed from external } \\
\text { sources of capital. } \\
\text { The most expensive elements are the } \\
\text { cogeneration system with fermentation } \\
\text { chambers and installations; these constitute } \\
\text { over } 60 \% \text { of the total expenditure. }\end{array}$} & \multirow{2}{*}{$\begin{array}{l}\text { The current expenses and } \\
\text { part of the } \\
\text { land purchase will be } \\
\text { covered from the } \\
\text { investor's own funds. }\end{array}$} & $\begin{array}{l}\text { Part of the electricity and heat } \\
\text { will be used for process } \\
\text { purposes. }\end{array}$ & \\
\hline 10 years & Operation of a biogas plant. & & & $\begin{array}{l}\text { More than } 90 \% \text { of the electricity } \\
\text { produced will be used for sale. }\end{array}$ & $\begin{array}{l}\text { Only } 20 \% \text { of the total heat } \\
\text { production will be } \\
\text { allocated for sale. }\end{array}$ \\
\hline 2028 & Repayment. & Grant settlement. & Own costs incurred. & & \\
\hline
\end{tabular}




\section{Results and Discussion}

\subsection{Analysis of Investment Profitability}

Prior to making a decision to invest in the biogas plant, it is important is to analyse all areas of the model, taking particular consideration of the desired rates that are a multidimensional reflection of the planned investment. According to the model, the investment account has been positive since 2018. Cash flow was shown to be positive in each period, which permitted investment.

Without the condition of discounting cash flows, a return on investment was found to be obtained after 33 quarters, i.e., in the 9th year of operation of the biogas plant. When the discounting cash flows was included, the investment was found to be returned one year later, i.e., in the 10th year of operation of the biogas plant. In the first year of operation, the rate of return for the biogas plant was found to amount to $4.1 \%$. This should be positively considered because investments are not very frequently profitable in the first periods; they only become profitable after 2-3 periods. Regarding depreciation, the rate of return was found to be $13.07 \%$, which is a very good result.

Both IRR and PI proved investment profitability and were found to be higher than the cost of capital, which led to the conclusion that this investment would be profitable in the long term. Importantly, return on investment could be expected within 3 years. For projects with large capital expenditure in relation to annual revenues, it is often stated that the return on investment should take place before the end of the 10th year of operation of the investment at full capacity, and this condition was observed in this analysed case.

Thus, the assumed model, the results of which are included in Table 3, showed the profitability of the biogas plant in the analysed configuration [55].

Table 3. Investment profitability [55].

\begin{tabular}{|c|c|c|c|c|c|}
\hline Rate & $\begin{array}{l}\text { Base } \\
\text { Value }\end{array}$ & $\begin{array}{l}\text { Rate Changes } \\
\text { No Subsidy }\end{array}$ & $\begin{array}{l}\text { Increase in External } \\
\text { Capital Costs up to } 8 \%\end{array}$ & $\begin{array}{l}\text { Decrease in } \\
\text { Revenue by } 20 \%\end{array}$ & $\begin{array}{l}\text { List of Operating } \\
\text { Costs by } 20 \%\end{array}$ \\
\hline $\begin{array}{l}\text { Simple payback } \\
\text { period (quarters) }\end{array}$ & 33 & 41 & 33 & 41 & 37 \\
\hline Simple payback period (years) & 8.25 & 10.25 & 8.25 & 10.25 & 9.25 \\
\hline $\begin{array}{l}\text { Full production capacity } \\
\text { launched (year) }\end{array}$ & 2016 & & & & \\
\hline $\begin{array}{l}\text { Rate of return for the first } \\
\text { period of full production } \\
\text { capacity launched }\end{array}$ & 4.10 & 1.40 & 4.72 & 0.70 & 2.80 \\
\hline $\begin{array}{l}\text { Rate of return (including } \\
\text { depreciation) }\end{array}$ & 13.07 & 10.00 & 13.70 & 9.60 & 4.00 \\
\hline DPP (quarters) & 37 & $\begin{array}{l}\text { no data } \\
\text { available }\end{array}$ & 41 & $\begin{array}{l}\text { no data } \\
\text { available }\end{array}$ & 45 \\
\hline DPP (years) & 9.25 & $\begin{array}{l}\text { no data } \\
\text { available }\end{array}$ & 10.25 & $\begin{array}{l}\text { no data } \\
\text { available }\end{array}$ & 11.25 \\
\hline IRR & 8.29 & $\begin{array}{l}\text { no data } \\
\text { available }\end{array}$ & 8.50 & $\begin{array}{l}\text { no data } \\
\text { available }\end{array}$ & 5.90 \\
\hline NPV (thousands, PLN) & 4733 & -386 & 3366 & -604 & 2320 \\
\hline PI & 7.9 & $\begin{array}{l}\text { no data } \\
\text { available }\end{array}$ & 4.93 & $\begin{array}{l}\text { no data } \\
\text { available }\end{array}$ & 2.4 \\
\hline
\end{tabular}

The primary economic returns for biogas plant investors in Poland come from revenues from the sale of products generated during the operation of the biogas plant: electricity produced and certificates of origin obtained, excess process heat obtained, digestate pulp in the form of fertilisers, and a fee for disposal of harmful and organic waste [109]. According to Igliński and collaborators [109], the income of a biogas plant with a capacity of $1 \mathrm{MW}_{\mathrm{el}}$ and $1 \mathrm{MW}_{\mathrm{t}}$ depends on what was used as the main substrate (slurry, slaughterhouse waste, maize silage, or organic municipal waste). The amount of biogas produced 
in this particular biogas plant was found to be approximately 3.7 million $\mathrm{m}^{3} /$ year. Assuming that the production of electricity and heat were $40 \%$ and $45 \%$, respectively (the plant need $10 \%$ electricity and $25 \%$ heat on its own), the amount of electricity and heat sold were found to be 7.5 and $7 \mathrm{GWht} /$ year, respectively. Of course, the substrates would be delivered free of charge, the utilisation of $1 \mathrm{Mg}$ of slaughter waste would amount to EUR $26.49 / \mathrm{Mg}$ (the purchase and storage cost), and the cost of maize silage would be EUR $28.7 / \mathrm{Mg}$. Therefore, the annual cost of the biogas plant was found to amount to EUR 0.88 million. An analysis of data [110] suggested that waste management would generate a profit of EUR 0.66-0.88 million, while the use of maize bought at the market price would lead to losses. Sales of "colour" certificates amount to EUR 0.75 million in revenue. The operating costs (without depreciation) of this biogas plant were found to be approximately EUR 0.88 million. The method of classifying investment outlays was shown to depend on the organisation of the process for the biogas plant. It seems that all the analysed biogas plants consist of two main elements: the type of fermentation tanks and the purchase of a cogeneration unit, which together account for about $20 \%$ of the capital expenditure. Gas purification and technology rights are also important in terms of costs [110]. The capital expenditure needed to build a $1 \mathrm{MW}_{\mathrm{el}}$ and $1 \mathrm{MW}_{\mathrm{el}} \mathrm{MWt}$ biogas plant is approximately EUR 2.64-2.86 million [111]. When estimating economic returns, one must consider other intangible benefits that are more difficult to measure. Locating biogas plants in the vicinity of potential customers reduces grid losses. In addition, creating distributed energy sources eliminates the need to expand transportation and distribution networks. The benefits of using cheaper energy (especially heat) from an independent source [112] are pro-social for the local community because they create new jobs and municipalities obtain tax from such activities.

\subsection{Project Sensitivity Risk Analysis}

Project sensitivity analysis was a development of the traditional discounted cash flow model. The analysis illustrated an impact of the change to a single base variable on a given investment. This analysis showed the change in the investment value as a result of the change in model risk parameters. The investment in the biogas plant also underwent a sensitivity analysis. How its key parameters would change as a result of changes in values was verified. Table 3 shows the project sensitivity. The impact on the model, the lack of subsidies, and the need to pay EUR 1.1 million with a commercial credit were firstly illustrated. We showed how the indexes would be affected by the failure to obtain grants and the need for additional external financing in the form of a commercial credit. The second modification of the model assumed an increase in costs of obtaining all foreign capital to $8 \%$. The third and fourth modifications were related to the operation of the biogas plant after its start-up. These data showed how the investment result would be affected by a decrease in revenue by $20 \%$ with unchanged costs and an increase in costs by $20 \%$ with unchanged revenues. The results for individual indexes after the modification of one selected parameter are shown in Table 3. On the basis of the results shown in Table 3, it can be concluded that both the lack of subsidies and the decrease in revenue by $20 \%$, i.e., over the entire period of 10 years, would make the investment unprofitable. On the other hand, the model showed that as operating and financial costs increase, profitability decreases and the payback period is extended. However, the investment was still shown to be somewhat profitable, although it already reached the lower limit for the increase in costs by $20 \%$ [55].

However, finance is not the only risk that should be considered when analysing the profitability of investments in a biogas plant. In this field, social factors play significant roles. In recent practice, the construction of biogas plants in Poland has encountered considerable social resistance. Residents of surrounding areas are afraid that new investments will lead to environmental degradation. Moreover, they fear that the operation of such facilities in their vicinity will adversely affect their living conditions. In addition, the RES is largely dependent on political decisions. As the EU provides a great deal of funding support for 
activities in this area, it appears that these investments will be even more subsidised and their economic effectiveness will increase [55].

Another issue comprises prices for certificates of origin and their turnover on the commodity exchange. After a wave of good prices, this market collapsed in 2012. The cost of producing $1 \mathrm{MWh}$ from RES is much more expensive than the cost of $1 \mathrm{MWh}$ produced in a traditional way. Operators do not offer very favourable prices. If this is compounded by low certificate prices, the balance sheet would end with a negative result, as shown by the sensitivity analysis.

Therefore, investment in biogas plants a high-risk investment, as is evident in numerous areas. In addition to financial parameters, investors must thoroughly analyse risks associated with the impact of the investment on the environment and the local community, which are two areas that cannot be parametrised in any way and may or may not significantly affect the success of an entire investment [55].

\subsection{Analysis of Investment Cash Flows}

The last area to be analysed as part of the viability of investment in biogas plants will was its financial feasibility. The model assumed that the investor would have funds to finance their investment. A significant proportion of the funds would come from external sources, i.e., commercial credits, soft credits, and subsidies. The own share in this model was assumed to be $10 \%$ of investment costs. Liabilities will be repaid to project financing institutions from the first year of operation of the biogas plant, i.e., 2018. In order to repay such liabilities, it would be necessary to start up the biogas plant so that it could generate revenues necessary to pay the amounts that would gradually become due.

Analysing the projected cash flow and financial result (Figure 2) showed that throughout the entire period of operation of the biogas plant (from 2018), the financial result would be positive. In addition, no liquidity problems would be observed. Cash flow would always be positive and in no way close to zero. Therefore, in terms of feasibility, the model did not assume any difficulties. Moreover, slight fluctuations in each of the analysed parameters would not have a negative impact on the outcome of the entire project [55].

\section{Cash [million EUR]}

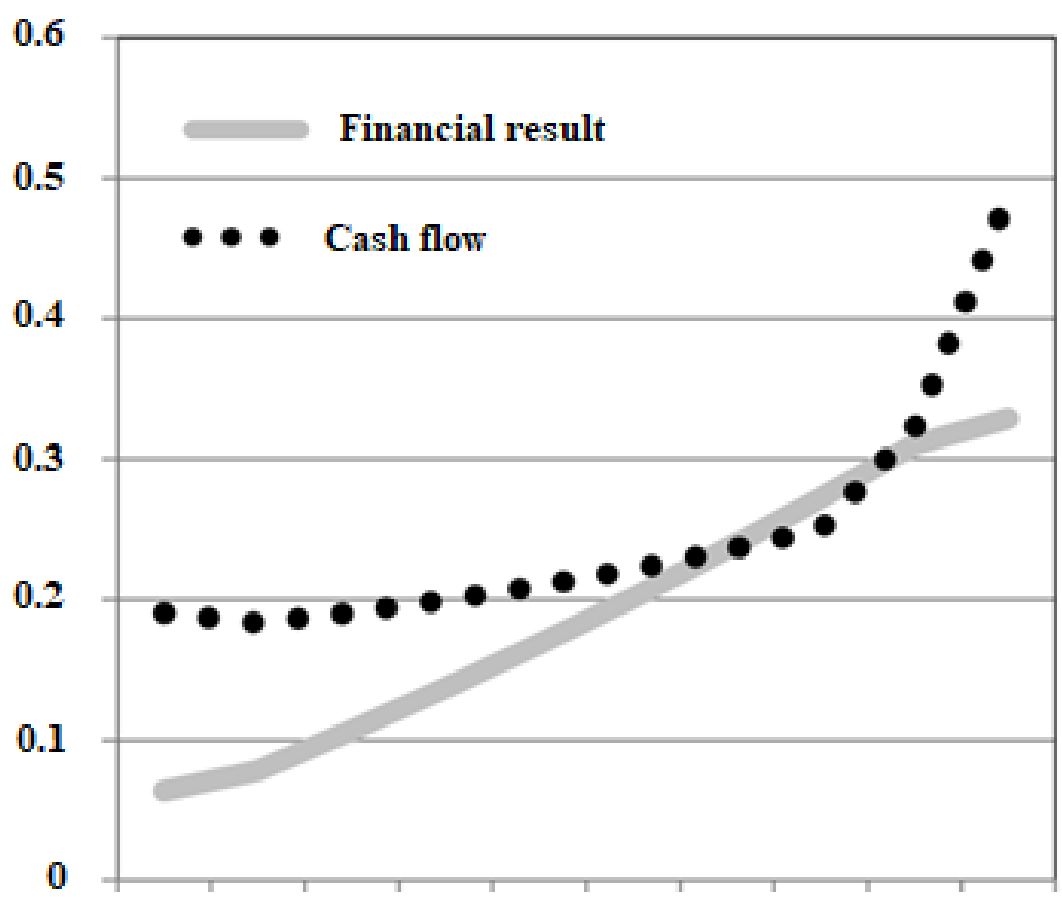

2018201920202021202220232024202520262027

Figure 2. Financial result and cash flow [55]. 
In the foreign literature, it is possible to notice a developed probabilistic risk index [113]. To demonstrate the calculation of the multi-disruption risk factor, it was decided to present a case study for a bioenergy park - an integrated material and energy synergy system for ancillary facilities to increase efficiency and reduce $\mathrm{CO}_{2}$ emissions. A probabilistic multiple disruption risk indicator was developed to measure the change in the net production of a bioenergy park based on exogenously defined power plant disruption scenarios. Such risk-based information can be used to develop risk-management measures to reduce network vulnerability by increasing system redundancy and diversity. Another example of the possible risk of economic profitability of biogas production is the "Croatian syndrome" [114]. The current promising growth of agricultural investment in Croatia leads to not only the implementation of new technologies and procedures but also increased public awareness of modern agricultural production; RES is a side effect, with a particular focus on biogas. Therefore, the question of total biogas potential for the agricultural sector in Croatia is very important. Some of the biggest obstacles to the use of biogas on Croatian farms are their geographical displacement and small size, which means that they are unable to provide economically viable biogas production. Therefore, urban biogas plants will play an important role in increasing the use of biogas in Croatian agriculture. The developed methodology can form the basis for a regional analysis of the biogas potential of the agricultural sector in Croatia. The value of agricultural biogas potential in Croatia is important because farms consume large amounts of energy in their daily operations, and part of this energy can be compensated for by RES such as biogas.

\subsection{Examples of Profitability Assessment of Investments in the Infrastructure of Agricultural Biogas Plants in Poland \\ 4.4.1. Example No. 1}

Three agricultural biogas plants located [8] in Palowice, Pawłówek, and Kiełpin were analysed. The first breeding farm in Palowice is located in Czerwionka-Leszczyny commune, Rybnik County. Its area is 7.4 ha. There are ten poultry houses in its territory [115]. The second analysed farm is located in Kiełpin, Złotów County. The farm breeds a maximum of 14,000 pigs with weights between 30 and $100 \mathrm{~kg}$. The third analysed farm is in Pawłówek, Przechlewo commune, Człuchów County. This farm breeds a maximum of 9200 pigs.

The assessment included the profitability of biogas production in agricultural biogas plants and their energy generation in a cogeneration unit for CHP generation. In addition, options for the construction and operation of the biogas plant were considered while considering the investor's own funds and the possibility of using external financing [61].

Table 4 shows calculations for an investment project carried out in commercial conditions. The data shown in Table 4 prove that the construction, start-up, and operation of biogas plants would involve high costs and are unprofitable for commercial variants. Therefore, the only chance for the success of the investment would be to apply for the largest possible subsidies for this purpose and preferential credits.

A further economic analysis was based on variants using subsidies from EU funds, preferential credits, and other options for financing investments from national and foreign funds-see Table 5 . 
Table 4. Statement of costs, profits, and savings of biogas investments in EUR [61].

\begin{tabular}{|c|c|c|c|c|}
\hline \multirow[t]{2}{*}{ Parameter } & \multirow{2}{*}{$\begin{array}{c}\text { Kiełpin } \\
\text { (Breeding of } \\
\text { Fattening Pigs) }\end{array}$} & \multicolumn{2}{|c|}{$\begin{array}{l}\text { Biogas Plant } \\
\text { Palowice } \\
\text { (Poultry Farm) }\end{array}$} & \multirow{2}{*}{$\begin{array}{c}\text { Pawłówek } \\
\text { (Breeding of } \\
\text { Fattening Pigs) }\end{array}$} \\
\hline & & First Variant & Second Variant & \\
\hline Total investment cost & $838,852.10$ & $706,401.77$ & $794,701.99$ & $949,227.37$ \\
\hline Annual investment costs & $41,942.60$ & $35,320.09$ & $39,735.10$ & $47,461.37$ \\
\hline Maintenance and operating costs & $12,362.03$ & $10,596.03$ & $11,479.03$ & $14,569.54$ \\
\hline Service personnel & 5298.01 & 4415.01 & 4856.51 & 6622.52 \\
\hline Measurements, analyses & 3311.26 & 2869.76 & 309.51 & 3973.51 \\
\hline Administration & 2207.51 & 1766.00 & 1986.75 & 2649.01 \\
\hline Insurances & 6622.52 & 5298.01 & 5960.26 & 7284.77 \\
\hline Others & 8167.77 & 6622.52 & 7505.52 & 9933.77 \\
\hline Total annual costs & $79,911.70$ & $66,887.42$ & $75,496.69$ & $92,494.48$ \\
\hline Savings on purchase: fuel, electricity & $1545.2525,386.31$ & $0.0017,660.0$ & $15,894.0417,660.0$ & $4856.5121,633.55$ \\
\hline Profit on sale of electricity surplus & $60,706.40$ & $43,267.114$ & $43,267.114$ & $54,083.89$ \\
\hline Total profit and savings & $85,430.46$ & $60,927.15$ & $76,821.19$ & $78,366.45$ \\
\hline Cost-effectiveness & +5518.76 & -5960.26 & +1324.50 & $-14,128.04$ \\
\hline
\end{tabular}

The data in Table 5 show that the investment would become highly profitable when the subsidy obtained a significant share. The simple payback period for the biogas plant in Kiełpin was 3.8 years, and it was 4.7 years for the plant in Palowice with a heating system. For other options, SPBT was 6.5 and 8.8 years—see Table 5.

In the most favourable variants, the analysed technologies were characterised by internal rates of return above the investment credit rate, i.e., $29.7 \%$ and $30.2 \%$ for Kiełpin and $26.3 \%$ and $27.0 \%$ for Palowice, with NPV ratios of EUR 238,732.01 and EUR 309,266.23 for Kiełpin and EUR 190.61 and EUR 251,632.23 for Palowice after 15 and 20 years, respectively. These investments were found to require the support of $75 \%$ of total costs.

For other options, the IRR was found to be similar to the interest rate of credits and guaranteed the profitability of the project at a level that allowed it to be recommended for implementation. They were found to require support of $60-70 \%$ of total investment costs.

The values of the indicators were as follows:

- $\quad$ Kiełpin: SPBT $=9.3$ years; $I R R=13.2 \%$ and $14.8 \%$ with NPV ratios of EUR 112,906.18 and EUR 183,438.41 after 15 and 20 years, respectively; subsidy at $60 \%$ of total costs.

- $\quad$ Palowice: SPBT $=9.3$ years and 8.6 years depending on the variant; IRR $=13.5 \%$ and $15.1 \%$ after 15 years with NPV of EUR 69,105.52 and EUR 112,737.09, respectively, and $14.5 \%$ and $16.0 \%$ after 20 years with NPV of EUR 111,143.27 and EUR 172,162.03, respectively; subsidy of $70 \%$ and $65 \%$ of total costs, respectively.

- $\quad$ Pawłówek: SPBT $=12.2$ years; IRR $=9.7 \%$ and $11.8 \%$ after 15 and 20 years with NPV ratios of EUR 37,129.80 and EUR 86,887.20, respectively; subsidy at 70\% of total costs.

The profitability threshold in Polish conditions was found to comprise investments in which a cogeneration unit producing at least $500 \mathrm{kWh}$ of electric energy and a second amount of heat energy per hour operates $24 \mathrm{~h}$ a day.

In conclusion, the conducted economic analysis of the use of biogas technologies showed their high variability in terms of cost-effectiveness and individual dependence on the specificity of the site and the use of different support mechanisms. The construction of an agricultural biogas plant under commercial conditions has not shown sufficient economic efficiency. Investing in biogas technology was found to be economically justified if it is possible to benefit from an external subsidy of at least $60-70 \%$ depending on the analysed case. The construction of large (over $500 \mathrm{~kW}$ of capacity) centralised agricultural biogas plants using CHP with at least $75 \%$ of the subsidies for the entire investment is currently the most cost-effective option [61]. 
Table 5. Economic indicator for biogas investment in Pawłówko [61].

\begin{tabular}{|c|c|c|c|c|c|c|c|c|}
\hline \multicolumn{2}{|c|}{ Time horizon } & \multicolumn{2}{|c|}{20 years } & Own share & \multicolumn{3}{|c|}{ EUR 142,384.11 } & $15 \%$ \\
\hline \multicolumn{2}{|c|}{ Capital expenditure } & \multicolumn{2}{|c|}{ EUR 949,227.37 } & Credit & \multicolumn{3}{|c|}{ EUR 94,922.74 } & $10 \%$ \\
\hline \multicolumn{2}{|c|}{ Discount rate } & \multicolumn{2}{|c|}{$7.0 \%$} & Interest & \multicolumn{3}{|c|}{ EUR 12,873.07 } & \\
\hline \multicolumn{2}{|c|}{ Income } & \multicolumn{2}{|c|}{ EUR 33,333.33 } & Subsidy & \multicolumn{3}{|c|}{ EUR 711,920.53 } & $75 \%$ \\
\hline $\begin{array}{l}\text { Period } \\
\text { (years) }\end{array}$ & $\begin{array}{l}\text { Revenue } \\
\text { (thousand) }\end{array}$ & $\begin{array}{l}\text { Capital } \\
\text { expenditure } \\
\text { (thousand) }\end{array}$ & $\begin{array}{l}\text { Capital } \\
\text { instalment } \\
\text { (thousand) }\end{array}$ & $\begin{array}{l}\text { Interest } \\
\text { instalment } \\
{[E U R]}\end{array}$ & $\begin{array}{l}\text { Cash flows } \\
\text { [EUR] }\end{array}$ & $\begin{array}{l}\text { Discount } \\
\text { rate }\end{array}$ & $\begin{array}{l}\text { PV } \\
\text { [EUR] }\end{array}$ & $\begin{array}{l}\text { NPV } \\
\text { [EUR] }\end{array}$ \\
\hline 0 & 0 & 645 & 0 & 0 & $-142,384.11$ & 1 & $-142,384.11$ & $-142,384.11$ \\
\hline 1 & 151 & 0 & 43 & 2340.62 & $21,500.44$ & 0.93 & $20,093.82$ & $-122,290.29$ \\
\hline 2 & 151 & 0 & 43 & 2106.40 & $21,734.66$ & 0.87 & $18,983.89$ & $-103,306.40$ \\
\hline 3 & 151 & 0 & 43 & 1872.41 & $21,968.65$ & 0.82 & $17,932.89$ & $-85,373.51$ \\
\hline 4 & 151 & 0 & 43 & 1638.41 & $22,202.65$ & 0.76 & $16,938.41$ & $-68,435.10$ \\
\hline 5 & 151 & 0 & 43 & 1404.42 & $22,436.64$ & 0.71 & $15,997.13$ & $-52,437.97$ \\
\hline 6 & 151 & 0 & 43 & 1170.20 & $22,670.86$ & 0.67 & $15,106.40$ & $-37,331.57$ \\
\hline 7 & 151 & 0 & 43 & 936.20 & $22,904.86$ & 0.62 & $14,264.02$ & $-23,067.55$ \\
\hline 8 & 151 & 0 & 43 & 702.21 & $23,138.85$ & 0.58 & $13,467.11$ & -9600.44 \\
\hline 9 & 151 & 0 & 43 & 468.21 & $23,372.85$ & 0.54 & $12,713.25$ & 3112.80 \\
\hline 10 & 151 & 0 & 43 & 234.00 & $23,607.06$ & 0.51 & $12,000.66$ & $15,113.47$ \\
\hline 11 & 151 & 0 & 0 & 0 & $33,333.33$ & 0.48 & $15,836.42$ & $30,949.89$ \\
\hline 12 & 151 & 0 & 0 & 0 & $33,333.33$ & 0.44 & $14,800.44$ & $45,750.11$ \\
\hline 13 & 151 & 0 & 0 & 0 & $33,333.33$ & 0.41 & $13,832.23$ & $59,582.34$ \\
\hline 14 & 151 & 0 & 0 & 0 & $33,333.33$ & 0.39 & $12,927.15$ & $72,509.71$ \\
\hline 15 & 151 & 0 & 0 & 0 & $33,333.33$ & 0.36 & $12,081.46$ & $84,591.17$ \\
\hline 16 & 151 & 0 & 0 & 0 & $33,333.33$ & 0.34 & $11,291.17$ & $95,882.34$ \\
\hline 17 & 151 & 0 & 0 & 0 & $33,333.33$ & 0.32 & $10,552.54$ & $106,434.88$ \\
\hline 18 & 151 & 0 & 0 & 0 & $33,333.33$ & 0.30 & 9862.03 & $116,296.91$ \\
\hline 19 & 151 & 0 & 0 & 0 & $33,333.33$ & 0.28 & 9217.00 & $125,513.91$ \\
\hline 20 & 151 & 0 & 0 & 0 & $33,333.33$ & 0.26 & 8613.91 & $134,127.81$ \\
\hline SPBT & & $\begin{array}{l}8.8 \text { years } \\
\text { after } 10 \text { years }\end{array}$ & & & & & & \\
\hline IRR & & $\begin{array}{l}9.2 \% \\
\text { after } 15 \text { years }\end{array}$ & & & & $\begin{array}{l}\text { NPV } \\
\text { [EUR] }\end{array}$ & $116,296.91$ & \\
\hline IRR & & $\begin{array}{l}14.6 \% \\
\text { after } 20 \text { years }\end{array}$ & & & & $\begin{array}{l}\text { NPV } \\
\text { [EUR] }\end{array}$ & $125,513.91$ & \\
\hline IRR & & $16.2 \%$ & & & & $\begin{array}{l}\text { NPV } \\
\text { [EUR] }\end{array}$ & $134,127.81$ & \\
\hline
\end{tabular}

\subsubsection{Example No. 2}

We analysed the variant for the construction of a $10 \mathrm{~kW}$ container agricultural microbiogas plant [116]. Such a system is suitable for agricultural farms with a minimum of 25 hectares or a pig density of more than 50 livestock units (LUs). This may be a guarantee that a farm can obtain part of its biogas substrates for free while at the same time managing the resulting waste, e.g., manure, slurry, manure, chicken manure, and waste from plant production. 
The estimated investment costs of particular components of the container agricultural micro-biogas plant are presented below.

A container with a fermentation tank and an agitator: this the most expensive part of an agricultural micro-biogas plant. The container can be constructed by most companies dealing with steel processing, construction of steel tanks, etc. The cost of its construction largely depends on raw materials. Due to the conditions in the digester, it is required to apply acid-resistant steel. Regardless, the same container housing can be made from carbon steel, and its cost is EUR 44,150.11-88,300.22.

The cogeneration system, including the so-called biogas path: a properly selected cogeneration engine may have a large impact on the amount of electric energy produced. It is estimated that equipment of lower power has a lower electrical efficiency of about $38-42 \%$ compared to engines used in larger plants at a cost of EUR 11,037.53-33,112.58.

Biogas tanks: the container that micro-biogas plants most frequently use is a flexible plastic tank placed directly on the container roof, and it has a cost of EUR 1324.50-2649.01.

Automation and control system: an appropriately selected automation reduces the amount of work needed to operate a plant. A system of tensometric scales and feeders coupled with a control system doses a substrate prepared earlier in the hopper to a biogas plant at a specified time; this has a cost of EUR 3311.26-5298.01.

Plant design and supervision: cost depends on the chosen plant construction path. By commissioning the construction of a micro-biogas plant from a specialised company with a "finished product", these costs are frequently included in the costs of the equipment. When establishing an individual plant, it is necessary to commission design works, with a cost of up to EUR 2649.01.

Digestion tank: if a slurry is produced on the farm, a tank already held by the farmer may be used to store digestate at a cost of EUR 883.00-1545.25.

Site preparation: a biogas plant container weighs several dozen tonnes, so it is necessary to harden the surface ground intended for the system; this has cost of EUR 1103.75-3973.51.

Staff training and laboratory supervision: a biogas plant is very sensitive to changes in the environment of the methane fermentation process, so it is necessary to train staff to operate the plant. In order to avoid problems with process continuity, it is recommended to commission a specialist entity to start up the plant and subsequently control any physical and chemical parameters; this costs EUR 3090.51-6622.52.

The cost to connect the power network and the measuring system is individually determined after obtaining connection conditions; this costs EUR 3311.26-4415.01.

The operating costs of the agricultural micro-biogas plant comprise the following factors:

- Substrate loading-about an hour a day.

- Maintenance and repair of technical equipment.

- Insurance.

It is estimated that the costs incurred for the performance of the aforesaid activities for a $10 \mathrm{~kW}$ micro-biogas plant amount to EUR 70,860.93-148,565.12.

Substrate extraction: it is recommended that the substrates used in low-power biogas plants should consist of waste produced on the farm. In this case, the cost of purchasing expensive substrates can be reduced as much as possible.

For example, for a $10 \mathrm{~kW}$ biogas plant using only a mixture of maize silage and slurry, the daily silage requirement is approximately $0.4 \mathrm{Mg}$. At a price of EUR 19.87 per $\mathrm{Mg}$ of this substrate, replacing it with another substrate may determine the profitability of the plant [116].

\subsubsection{Example No. 3}

The breakdown of capital expenditures for small biogas plants in the member states of the EU showed a very strong dependence of the amount of unit capital expenditure on the size of the biogas plant. We found that specific capital expenditures for biogas plants up to $500 \mathrm{~kW}_{\mathrm{el}}$ logarithmically decreases as the installed capacity increases [117]. 
A biogas plant with a capacity of $100 \mathrm{~kW}_{\mathrm{el}}$ from a foreign contractor would cost EUR 618,101.55. Market information showed that in Polish conditions, with the use of Polish components and technology suppliers, such an investment could be realised at a cost of EUR 353,200.88. However, some Polish technology suppliers and contractors would be able to make an investment of $60 \mathrm{~kW}_{\mathrm{el}}$ at a cost of approximately EUR 220,750.55 because $20-30 \%$ of expenditures come from purchasing the cogeneration unit and domestic producers have a quite wide range of equipment.

The decisive element of the profitability analysis was the balance of operating costs, financial costs, and revenues. If, after some time, i.e., a payback period, the balance sheet is positive, the investment is profitable. The most important cost item of a small biogas plant is the capital expenditure, which usually (per unit of installed capacity) increases as the scale or size of the investment decreases. In practice, if the cost of raising capital for the construction of a biogas plant is omitted, a profitability analysis can be carried out on the basis of a comparison of annual costs in which the capital expenditure represents depreciation and annual revenues.

The cost of purchase and logistics of substrates delivery for maize silage was found to be EUR 22.08-26.49 per Mg, including storage costs; for slurry, this cost was found to amount to EUR 0-5.52 per Mg. This cost also includes costs of the transport of substrates from the place of waste generation or plant production to the biogas plant.

The cost of spreading fertiliser on fields was found to eb EUR 2.21-19.87 per hectare. A small biogas plant will need several dozen hectares of land for fertilisation.

Taxes, fees, and charges:

- Corporate income tax.

- Real estate taxes at local rates.

Repairs, depreciation, and operation:

- Depreciation of equipment, i.e., annual capital expenditure.

- Overhaul, repair and maintenance services; under German conditions, these usually amount to around $10 \%$ of annual operating costs.

Others:

- Property and third-party liability insurance.

- Salaries.

- Facility security.

- Office services.

- $\quad$ Physical and chemical analyses.

- Legal and financial services.

The average electricity sales price in the competitive market in 2010 was found to be equal to 43.12 EUR/MWh. The average price of heat from RES in 2010 (according to the report of the President of the Energy Regulatory Office) was 8.52 EUR/GJ, but our model showed that it was lower by 4.42-5.52 EUR/GJ.

The sale of certificates of origin is also significant:

- $\quad$ Average price of green certificates on the Polish Power Exchange in September 2010: 60.87 EUR/MWh; the regulations were in force until the end of 2017.

- Average price of cogeneration certificates (yellow) for the plant of below $1 \mathrm{MW}_{\mathrm{el}}$ on the Polish Power Exchange in September 2010: 27.51 EUR/MWh; the regulations were in force until the end of 2012.

The fertiliser sale price or transfer fee was, in practice, found to be $4.42-5.52 \mathrm{EUR} / \mathrm{Mg}$ depending on nitrogen, phosphorus, and potassium contents.

Due to numerous sources of costs and revenues, as well as the changing laws and regulations of the support system, it is quite complicated to calculate the profitability of constructing biogas plants, especially agricultural micro-biogas plants. The discussed sources of costs and revenues are characteristic of an industrial cogeneration plant. The domestic market still lacks a full and proven technological offer of micro-biogas plants, 
including biogas plants with the simplest construction and small containers. In this necessarily simplified "business model", not all cost and revenue items of an agricultural biogas plant are fully reflected [116].

\subsection{Examples of Management Models}

By comparing the available investment models, e.g., the model for assessing success in project management, it is possible to notice the matrix characteristics necessary for the implementation of an investment model. The authors of [118] presented an expert, fuzzy model of project effectiveness evaluation that was implemented using fuzzy logic. First, the basic theoretical principles of project success rate, fuzzy sets, and fuzzy logic, and fuzzy model for project success rate evaluation were introduced. The fuzzy model was implemented in the MATLAB software environment using the Fuzzy Logic Toolbox application, where it was also verified and refined. Experimenting with a fuzzy model allowed the authors to simulate the uncertainty that is always present in projects. The proposed fuzzy model is a tool that allows project managers to quickly assess the success of a project and be able to apply the right measures at the right time. Similarly, analogous to the hierarchical mixed model with random effects of time and industry, this model allows for the study of multilevel data that are not independent [119]. Slovak and Czech companies were found to manipulate incomes to similar extents, and Hungarian companies increase accounting profit more than other examined countries controlling bankruptcylife cycle effect; however, there were no differences in accounting manipulations across industries. These results suggest that start-ups and failing firms deliver financial statement curves to obtain more favourable debt transactions and that estimating discretionary settlements using life-cycle sub-samples could improve the predictive power of accrual income management models. Considering the abovementioned model solutions and practical examples, it should be stated that projects implemented in the area of RES in the biogas industry without support (colour certificates of energy origin, subsidies, and preferential loans) simply do not pay off because NPV $<0$ and IRR is lower than the discount rate.

It is also important to prepare an energy balance that allows one to estimate the amount of produced electricity and heat. Thus far, there have been very few projects that have resulted in the production of biogas (biomethane) that can be pumped into the network after cleaning and enrichment.

When developing models of financial and economic analysis of agricultural biogas plant construction projects, problems related to the so-called "energy quality" of the substrates arise. This is important because the chemical energy in the final fermentation process is used to power the cogeneration system. In principle, these data are based on tables published in various types of publications, but they are general data. It turns out that, following general revenues, the energy quality of the substrates is the most sensitive of the studied variables. This means that the values of the dry matter contents in the substrates and the dry organic matter contents in the dry matter could significantly affect the efficiency of a biogas plant construction project. Substrates should be tested, and the values resulting from the results of these tests should be included in the energy balance.

It is also worth paying attention to the estimated revenues of a project. There are basically two items: the first comprises revenues from the sale of electricity and heat and revenues from the sale of colour certificates. The second comprises the basis for revenues from certificates that confirm the production of "green energy", i.e., green certificates. In a small number of cases, fees for the disposal of waste, which are the substrates, can also be assumed in the revenue items.

When analysing biogas infrastructure for 18-21 years (while considering that there are revenues from colour certificates throughout the life of an economic biogas project), we found that the investment efficiency increased for the model when assuming $100 \%$ sale or use of thermal energy. Of course, it should be assumed that about $25-30 \%$ of heat would be used to maintain a stable temperature of the mesophilic transformation process 
in reactors (fermentation tanks), the stability of which largely determines the efficiency of the anaerobic digestion process. So, at the level of preparing a purposefulness study or a pre-investment study, if one wants to obtain the maximum value of discounted, cumulated, free cash flows, one should ensure $100 \%$ use (or sale) of the remaining heat energy. In order for this condition to be met, investment outlays should be increased by building or expanding heat substations. The purchase of a ready-made agricultural biogas plant, in which heat (apart from some for own needs) is not used in the economic infrastructure is a negative outcome.

Currently, the most common form of investment analysis is the use of a sensitivity analysis and the estimation of profitability thresholds and safety margins for various examined variables. This can be done using IT tools in Invest for Excel (Datapartner Oy, Raatihuoneenkatu 8 A, 06100 Porvoo, Finland). Soft risks (e.g., organisational and legal) should be given an appropriate status (high, medium, or low), and a description of the risk itself and information on when it may occur and the possibilities of minimizing it should be provided.

In order to implement a profitable project to build an agricultural biogas plant and make the right investment decision, the following are the conditions for the success of a business venture:

- Constant supply stream of substrates guaranteed for a minimum of 15-18 years.

- Close access to substrates.

- Guaranteed sale price of electricity (auction price).

The following problems can be observed in existing conventional technological solutions:

- Correct maintenance of the technological regime, which is closely related to the conversion of chemical energy contained in substrates into energy contained in biogas. Process efficiency should be much higher than assumed in the technological model. The total selling price of electricity does not cover the costs of obtaining substrates as well as operating costs and credit obligations.

- $\quad$ Substrate extraction, often largely based on maize silage and primary organic fuel for fermentation, is not available in the quantity and quality assumed at the beginning. Farmers are oriented to profit from selling corn and are not interested in long-term contracts that force them to make continuous deliveries at a certain price.

- The prices of colour certificates are at a very low level, which (together with the sale of electricity and heat) does not guarantee that all operational costs and liability repayment resulting from obtaining foreign capital (most often investment loans) will be covered.

\subsection{Risks and Threats}

The construction of biogas plants is undoubtedly a very large investment project. It requires future investors to have a significant amount of money, good creditworthiness, and broad knowledge of the many fields that permeate one another at the planning and execution stages. As one way to obtain green energy, a biogas plant can be a cost-effective tool. A model analysis of the construction and operation of a biogas plant has proven that it is an economically viable investment.

However, the high risk of investing funds in this field is significant. This risk must be considered at every stage of investment planning, as well as at a later stage during its operation. Moreover, the biogas market is characterised by many risks that must also be taken into account in the entire analysis. The risks can be divided into:

- Social.

- Organisational.

- $\quad$ Technical and technological.

- Economic and legal.

Social risk is characterised by: 
- The negative perception of future investors by the inhabitants of the areas where biogas plants are planned to be constructed.

- Concerns of future investors about the high volatility of the sector.

Organisational risk is distinguished by:

- The lack of local land master plans.

- The lack of substantive preparation of officials to conduct investments in the sector.

- The organisational fragmentation of the sector in the country.

- The need to correlate heat reception with biogas production, especially in rural areas where heat transfer is impossible (rural areas have no heating infrastructure).

- The lack of national research laboratories and support centres for future investors.

- $\quad$ The lack of reliable investment advice.

Technical and technological risk occurs through:

- The temptation to invest in large biogas plants, which bring higher revenues and allow for higher rates of return on employed capital.

The economic and legal risk is:

- The lack of stable support for RES in legislation.

- $\quad$ High capital barriers to the construction of biogas plants.

- The strong position of energy companies in the market and the need to comply with their requirements, which are frequently excessively high for farmers who would like to start business in this field.

- Bureaucracy when applying for public support.

- A long payback period.

Poland has a very high potential for biogas (the country has about $12 \%$ of all biomass energy resources in the entirety of Europe [120]), but we still do not know how to effectively use it. A lack of technological support from the leading scientific centres in Poland has widened the gap in this field. Capital intensity also plays a major role. High financial expenditures combined with a long payback period can only change if the production of individual components for the construction of biogas plants is carried out on a larger scale in Poland. In the long term, the benefits for future investors are not defined either. Although the documents developed by the Ministry of Economy in the form of a guide for investors interested in building agricultural biogas plants [83] have dispelled many doubts, there is still a gap in the market because the documents do not provide readymade solutions. It is necessary to make further attempts to develop practical models of functioning for such innovative solutions. Recently, solutions for biogas plants have been in the literature [121].

Future research should concern the profitability of the project for both the investor and equity capital. From the point of view of equitable capital involvement in the context of the estimated financial efficiency ratios for other technologies used in the agricultural biogas plant industry, a return on equity is expected when assuming short-term (several years) operational support from the sale of electricity with the use of annual progression, especially for agricultural biogas plants at individual farms.

The impact of this article on society could be significant, because the amount of investment outlays and rates of subsidies to electricity are of key importance for the profitability of biogas plants. This suggestion is not innovative but indicates the cognitive value of the problem under consideration: the universality of the application of the investment model.

The guarantee of profitability of agricultural biogas plants is the durability and shape of future support mechanisms in the form of both bonuses for the production of energy from renewable sources and subsidies. Lowering investment outlays may also take place thanks to other mechanisms, e.g., the universality of implementations may initiate a reduction of costs due to the scale effect of biogas plants used in practice at individual farms.

The biogas sector in Poland in the conditions of individual farms expects the development of an investment model to demonstrate the calculated profitability of the investment. Currently, there are many unknowns because most models are borrowed from industrial 
biogas plants, which is, in principle, inadequate for the further development of this very innovative sector. The authors of this paper have discussed examples of solutions, enabling the reader to gain insight into various methods and proposals for investments carried out so far. It may seem chaotic, but this is what the characterised biogas market looks like in the context of the implementation of biogas projects. The authors of this article have offered some guidelines for understanding investing in this sensitive sector of private farming, so they count all the more on the understanding and recognition of systematizing the constantly evolving market of renewable energies.

This article emphasises the bridge between theory and practice applied in the agricultural biogas plant industry and highlights the applied analytical methods, showing which combinations of subsidies for clean energy and installations of different kinds of power equate the competitive position of installations of different sizes and amounts of investment expenditure.

\section{Conclusions}

A CE appeals to a sense of responsibility and intergenerational solidarity, but it will not become a tool for transforming companies until it has proven its effectiveness in the form of economically verified business models. CE business models have proven their effectiveness when they are part of wider projects or they achieve economic efficiency despite competition. In current market conditions, however, it seems impossible in most cases to design a permanent model that closes the cycle of organic waste without new regulatory solutions.

There is a strong need to transform biowaste into bioenergy technologies (including the production of biogas such as biomethane).

There is increasing ethical pressure to introduce processes other than linear processing models, i.e., from raw material to waste. The dominant model of economic evaluation, focused on short-term rates of return, still makes it difficult to replace the evaluation of economic efficiency with a broader ecological and economic approach.

Analyses have shown that investment is sensitive to changes in market conditions but bring positive value in the economic balance in the long term as a result of high investment costs; therefore, financial support is important at the stage of building a biogas plant.

The considerations contained in this article present an investment model for an agricultural biogas plant. We developed structure of investment categories for biogas plants, in which the dominant expenditure of over $30 \%$ found to be the fermentation chamber and cogeneration.

It is advisable to look for waste substrates (pork slurry) for which the cost is as low as possible. A business model for biogas plants was developed based and the profitability of investment; an investment profitability analysis was presented which showed that the investment profitability is higher than the cost of capital, which means that in the long term, the investment in agricultural biogas plants is profitable. A sensitivity analysis of the project, which was an extension of the traditional discounted cash flow model, was also performed. It was shown that both a lack of subsidies and a decrease in revenues by $20 \%$, i.e., over the entire 10 -year period, make the investment unprofitable. The financial results and cash flows were interpreted, and we found that the financial result is positive throughout the entire period of operation of the biogas plant.

Examples of investment profitability assessment in the infrastructure of agricultural biogas plants in Poland, including the costs, profits and savings of biogas investments for economic indicators and variants of energy infrastructure of biogas plants, have been presented. It has been shown that the Polish market still lacks a complete and proven technological offer of micro-biogas plants, including the simplest-to-build small-container biogas plants. Therefore, there is a need to develop a simplified "business model" for agricultural biogas plants for individual farms. 
Author Contributions: Conceptualisation, G.W.; data curation, J.D., K.B., A.K. and G.W.; formal analysis, K.K., M.K. and G.W.; funding acquisition, K.K., M.K. and G.W.; investigation, J.D., K.B., D.A., B.D., A.K. and G.W.; methodology, D.A., B.D., A.K. and G.W.; project administration, G.W.; resources, K.K., M.K., S.S., R.K. and G.W.; software, K.K., M.K. and G.W.; supervision, G.W.; validation, K.K., M.K., S.S., N.B., N.K., R.K. and G.W.; visualisation, K.K., M.K., S.S., N.B., N.K., R.K. and G.W.; writing-original draft, G.W.; writing — review and editing, G.W. All authors have read and agreed to the published version of the manuscript.

Funding: This study was conducted as part of the project financed by (1) National Centre for Research and Development implemented under the BIOSTRATEG program, contract No. BIOSTRATEG1/269056/5/NCBR/2015; (2) the Research Task (statutory) No. 11/79/2019 “Developing a model describing the gas permeability of anisotropic porous materials in the aspect of adhesive hydrodynamics for agroenergetic applications" implemented by the Renewable Energy Department in the Poznan Branch, Institute of Technology and Life Sciences-National Research Institute, Falenty, and cooperation with the Lviv National Agrarian University and Scientific and Practical Centre of the National Academy of Sciences of Belarus for Agricultural Mechanisation and Jacob of Paradyz University in Gorzow Wielkopolski and University of Life Sciences in Lublin. The APC was funded by University of Life Sciences in Lublin.

Institutional Review Board Statement: Not applicable.

Informed Consent Statement: Not applicable.

Data Availability Statement: The data presented in this study are available on request from the corresponding author.

Conflicts of Interest: The authors declare no conflict of interest. The funders had no role in the design of the study; in the collection, analyses, or interpretation of data; in the writing of the manuscript; or in the decision to publish the results.

\section{References}

1. Yazan, D.M.; Cafagna, D.; Fraccascia, L.; Mes, M.; Pontrandolfo, P.; Zijm, H. Economic sustainability of biogas production from animal manure: A regional circular economy model. Manag. Res. Rev. 2018, 41, 605-624. [CrossRef]

2. European Commission. Moving towards a Circular Economy. 2015. Available online: http://ec.europa.eu/environment/circulareconomy/index_en.htm (accessed on 29 October 2021).

3. Bruckner, M.; Giljum, S.; Lutz, C.; Wiebe, K.S. Materials embodied in international trade-Global material extraction and consumption between 1995 and 2005. Glob. Environ. Chang. 2012, 22, 568-576. [CrossRef]

4. Bocken, N.M.; de Pauw, I.; Bakker, C.; van der Grinten, B. Product design and business model strategies for a circular economy. J. Ind. Prod. Eng. 2016, 33, 303-308. [CrossRef]

5. Rolewicz-Kalińska, A.; Lelicińska-Serafin, K.; Manczarski, P. The circular economy and organic fraction of municipal solid waste recycling strategies. Energies 2020, 13, 4366. [CrossRef]

6. Malinauskaite, J.; Jouhara, H.; Czajczyńska, D.; Stanchev, P.; Katsou, E.; Rostkowski, P.; Thorne, R.J.; Colón, J.; Ponsá, S.; Al-Mansour, F.; et al. Municipal solid waste management and waste-to-energy in the context of a circular economy and energy recycling in Europe. Energy 2017, 141, 2013-2044. [CrossRef]

7. Tisserant, A.; Pauliuk, S.; Merciai, S.; Schmidt, J.; Fry, J.; Wood, R.; Tukker, A. Solid waste and the circular economy: A global analysis of waste treatment and waste footprints. J. Ind. Ecol. 2017, 21, 628-640. [CrossRef]

8. Borrello, M.; Caracciolo, F.; Lombardi, A.; Pascucci, S.; Cembalo, L. Consumers' perspective on circular economy strategy for reducing food waste. Sustainability 2017, 9, 141. [CrossRef]

9. Jędrczak, A. Composting and fermentation of biowaste-Advantages and disadvantages of processes. Civ. Environ. Eng. Rep. 2019, 28, 71-87. [CrossRef]

10. Abad, V.; Avila, R.; Vicent, T.; Font, X. Promoting circular economy in the surroundings of an organic fraction of municipal solid waste anaerobic digestion treatment plant: Biogas production impact and economic factors. Bioresour. Technol. 2019, $283,10-17$. [CrossRef]

11. Demirbas, A. Biogas production from the organic fraction of municipal solid waste. Energy Sources Part. A Recovery Util. Environ. Eff. 2006, 28, 1127-1134. [CrossRef]

12. Mardoyan, A.; Braun, P. Analysis of Czech subsidies for solid biofuels. Int. J. Green Energy 2015, 12, 405-408. [CrossRef]

13. Maroušek, J.; Strunecký, O.; Kolář, L.; Vochozka, M.; Kopecký, M.; Maroušková, A.; Batt, J.; Poliak, M.; Šoch, M.; Bartoš, P.; et al. Advances in nutrient management make it possible to accelerate biogas production and thus improve the economy of food waste processing. Energy Sources Part A Recovery Util. Environ. Eff. 2020, 1-10. [CrossRef]

14. Bhatia, S.K.; Joo, H.S.; Yang, Y.H. Biowaste-to-bioenergy using biological methods-A mini-review. Energy Convers. Manag. 2018, 177, 640-660. [CrossRef] 
15. Ludbrook, F.; Michalikova, K.F.; Musova, Z.; Suler, P. Business models for sustainable innovation in industry 4.0: Smart manufacturing processes, digitalization of production systems, and data-driven decision making. J. Self-Gov. Manag. Econ. 2019, 7, 21-26.

16. Milward, R.; Popescu, G.H.; Michalikova, K.F.; Musova, Z.; Machova, V. Sensing, smart, and sustainable technologies in industry 4.0: Cyber-physical networks, machine data capturing systems, and digitized mass production. Econ. Manag. Financ. Mark. 2019, $14,37-43$.

17. Cimpan, C.; Rothmann, M.; Hamelin, L.; Wenzel, H. Towards increased recycling of household waste: Documenting cascading effects and material ef fi ciency of commingled recyclables and biowaste collection. J. Environ. Manag. 2015, 157, 69-83. [CrossRef]

18. Pearce, D.W.; Turner, R.K. Economics of Natural Resources and the Environment; Harvester Wheatsheaf: New York, NY, USA; London, UK, 1990.

19. Posłuszny, K. Circular Economy Business Models in the Field of Plastics. Circular Economy, Models, Tools, Indicators; Iwaszczuk, N., Krzysztof, O., Eds.; AGH Publishing Houses: Krakow, Poland, 2021; pp. 9-22. ISBN 978-83-66727-06-9.

20. López, M.V.; Garcia, A.; Rodriguez, L. Sustainable development and corporate performance: A study based on the Dow Jones sustainability index. J. Bus. Ethics 2007, 75, 285-300. [CrossRef]

21. Murray, A.; Skene, K.; Haynes, K. The circular economy: An interdisciplinary exploration of the concept and application in a global context. J. Bus. Ethics 2015, 140, 369-380. [CrossRef]

22. Urbinati, A.; Chiaroni, D.; Chiesa, V. Towards a new taxonomy of circular economy business models. J. Clean. Prod. 2017, 168, 487-498. [CrossRef]

23. Ghisellini, P.; Cialani, C.; Ulgiati, S. A review on circular economy: The expected transition to a balanced interplay of environmental and economic systems. J. Clean. Prod. 2016, 114, 11-32. [CrossRef]

24. Schaltegger, S.; Lüdeke Freund, F.; Hansen, E.G. Business models for sustainability: A coevolutionary analysis of sustainable entrepreneurship, innovation, and transformation. Organ. Environ. 2016, 29, 264-289. [CrossRef]

25. Nosratabadi, S.; Mosavi, A.; Shamshirband, S.; Zavadskas, K.; Rakotonirainy, A.; Chau, K.W. Sustainable business models: A review. Sustainability 2019, 11, 1663. [CrossRef]

26. Klasa, A.; Olba-Zięty, E. Circular economy (CE) in agriculture and horticulture. In Circular Economy; Warmińsko-Mazurski Ośrodek Doradztwa Rolniczego: Olsztyn, Poland, 2019; pp. 2-7; 14-16.

27. Gołębiowski, K.; Holewa-Rataj, J.; Koch-Kopyszko, S.; Kukulska-Zając, E.; Krysiuk, I.; Rogowska, D.; Rogulska, M.; Samson-Bręk, I.; Siuda, A.; Stępień, A.; et al. Barriers to the development of the biomethane sector in Poland and proposed solutions. In Biała Book of Biomethane; Coalition for Biomethane: Warsaw, Poland, 2020.

28. Gołaszewski, J. The use of agricultural substrates in biogas plants in Poland. Adv. Agric. Sci. 2011, 2, 69-94.

29. Caposciutti, G.; Baccioli, A.; Ferrari, L.; Desideri, U. Biogas from anaerobic digestion: Power generation or biomethane production? Energies 2020, 13, 743. [CrossRef]

30. Hosseini Koupaie, E.; Azizi, A.; Bazyar Lakeh, A.A.; Hafez, H.; Elbeshbishy, E. Comparison of liquid and dewatered digestate as inoculum for anaerobic digestion of organic solid wastes. Waste Manag. 2019, 87, 228-236. [CrossRef]

31. Blades, L.; Morgan, K.; Douglas, R.; Glover, S.; De Rosa, M.; Cromie, T.; Smyth, B. Circular biogas-based economy in a rural agricultural setting. Energy Procedia 2017, 123, 89-96. [CrossRef]

32. Lillo, P.; Ferrer-Martí, L.; Fernández-Baldor, Á.; Ramírez, B. A new integral management model and evaluation method to enhance sustainability of renewable energy projects for energy and sanitation services. Energy Sustain. Dev. 2015, $29,1-12$. [CrossRef]

33. Tappen, S.J.; Aschmann, V.; Effenberger, M. Lifetime development and load response of the electrical efficiency of biogas-driven cogeneration units. Renew. Energy 2017, 114, 857-865. [CrossRef]

34. Pöschl, M.; Ward, S.; Owende, P. Evaluation of energy efficiency of various biogas production and utilization pathways. Appl. Energy 2010, 87, 3305-3321. [CrossRef]

35. Gebrezgabher, S.A.; Meuwissen, M.P.M.; Prins, B.A.M.; Lansink, A.G.O. Economic analysis of anaerobic digestion-A case of Green power biogas plant in The Netherlands. NJAS Wageningen J. Life Sci. 2010, 57, 109-115. [CrossRef]

36. D'Adamo, I.; Falcone, P.M.; Ferella, F. A socio-economic analysis of biomethane in the transport sector: The case of Italy. Waste Manag. 2019, 95, 102-115. [CrossRef] [PubMed]

37. Baccioli, A.; Antonelli, M.; Frigo, S.; Desideri, U.; Pasini, G. Small scale bio-LNG plant: Comparison of different biogas upgrading techniques. Appl. Energy 2018, 217, 328-335. [CrossRef]

38. Nguyen Duc, K.; Nguyen Duy, V.; Hoang-Dinh, L.; Nguyen Viet, T.; Le-Anh, T. Performance and emission characteristics of a port fuel injected, spark ignition engine fueled by compressed natural gas. Sustain. Energy Technol. Assess. 2019, 31, 383-389. [CrossRef]

39. Pasini, G.; Baccioli, A.; Ferrari, L.; Antonelli, M.; Frigo, S.; Desideri, U. Biomethane grid injection or biomethane liquefaction: A technical-economic analysis. Biomass Bioenergy 2019, 127, 105264. [CrossRef]

40. Salama, E.; Jeon, B.; Kurade, M.B.; Patil, S.M.; Usman, M.; Li, X.; Lim, H. Enhanced anaerobic co-digestion of fat, oil, and grease by calcium addition: Boost of biomethane production and microbial community shift. Bioresour. Technol. 2019, $296,122353$. [CrossRef]

41. De Clercq, D.; Wen, Z.; Fei, F.; Caicedo, L.; Yuan, K.; Shang, R. Interpretable machine learning for predicting biomethane production in industrial-scale anaerobic co-digestion. Sci. Total Environ. 2019, 712, 134574. [CrossRef] 
42. Cucchiella, F.; D'Adamo, I.; Gastaldi, M. An economic analysis of biogas-biomethane chain from animal residues in Italy. J. Clean. Prod. 2019, 230, 888-897. [CrossRef]

43. Baccioli, A.; Ferrari, L.; Guiller, R.; Yousfi, O.; Vizza, F.; Desideri, U. Feasibility analysis of bio-methane production in a biogas plant: A case study. Energies 2019, 12, 473. [CrossRef]

44. Calise, F.; Cremonesi, C.; de Notaristefani di Vastogirardi, G.; d'Accadia, M.D. Technical and economic analysis of a cogeneration plant fueled by biogas produced from livestock biomass. Energy Procedia 2015, 82, 666-673. [CrossRef]

45. Holm-Nielsen, J.B.; Al Seadi, T.; Oleskowicz-Popiel, P. The future of anaerobic digestion and biogas utilization. Bioresour. Technol. 2009, 100, 5478-5484. [CrossRef] [PubMed]

46. Zepter, J.M.; Engelhardt, J.; Gabderakhmanova, T.; Marinelli, M. Empirical validation of a biogas plant simulation model and analysis of biogas upgrading potentials. Energies 2021, 14, 2424. [CrossRef]

47. Haas, J.; Cebulla, F.; Cao, K.; Nowak, W.; Palma-Behnke, R.; Rahmann, C.; Mancarella, P. Challenges and trends of Energy storage expansion planning for flexibility provision in low-carbon power systems-A review. Renew. Sustain. Energy Rev. 2017, 80, 603-619. [CrossRef]

48. European Commission. A Hydrogen Strategy for a Climate-Neutral Europe; European Commission: Brussels, Belgium, 2020.

49. Scarlat, N.; Dallemand, J.-F.; Monforti-Ferrario, F.; Banja, M.; Motola, V. Renewable energy policy framework and bioenergy contribution in the European union-An overview from national renewable energy action plans and progress reports. Renew. Sustain. Energy Rev. 2015, 51, 969-985. [CrossRef]

50. Dotzauer, M.; Pfeiffer, D.; Lauer, M.; Pohl, M.; Mauky, E.; Bär, K.; Sonnleitner, M.; Zörner, W.; Hudde, J.; Schwarz, B.; et al. How to measure flexibility_Performance indicators for demand driven power generation from biogas plants. Renew. Energy 2019, 134, 135-146. [CrossRef]

51. Mauky, E.; Jacobi, H.F.; Liebetrau, J.; Nelles, M. Flexible biogas production for demand-driven energy supply-Feeding strategies and types of substrates. Bioresour. Technol. 2015, 178, 262-269. [CrossRef] [PubMed]

52. Mauky, E.; Weinrich, S.; Nägele, H.J.; Jacobi, H.F.; Liebetrau, J.; Nelles, M. Model predictive control for demand-driven biogas production in full scale. Chem. Eng. Technol. 2016, 39, 652-664. [CrossRef]

53. Korberg, A.D.; Skov, I.R.; Mathiesen, B.V. The role of biogas and biogas-derived fuels in a $100 \%$ renewable energy system in Denmark. Energy 2020, 199, 117426. [CrossRef]

54. Shah, F.A.; Mahmood, Q.; Rashid, N.; Pervez, A.; Raja, I.A.; Shah, M.M. Co-digestion, pretreatment and digester design for enhanced methanogenesis. Renew. Sustain. Energy Rev. 2015, 42, 627-642. [CrossRef]

55. Przesmycka, A.; Podstawka, M. Economic efficiency of investments in agricultural biogas plants. Association of agricultural and agribusiness economists. Ann. Sci. 2016, 6, 176-182.

56. Theuerl, S.; Herrmann, C.; Heiermann, M.; Grundmann, P.; Landwehr, N.; Kreidenweis, U.; Prochnow, A. The future agricultural biogas plant in Germany: A vision. Energies 2019, 12, 396. [CrossRef]

57. Kemausour, F.; Adaramola, M.S.; Morken, J. A review of commercial biogas systems and lessons for Africa. Energies 2018, 11, 2984. [CrossRef]

58. Wałowski, G. Multi-phase flow assessment for the fermentation process in mono-substrate reactor with skeleton bed. J. Water Land Dev. 2019, 42, 150-156. [CrossRef]

59. German Biogas Association. Biogas Market Data in Germany 2017/2018. Available online: https://www.biogas.org/edcom/ webfvb.nsf/id/DE_Branchenzahlen/\$file/18-07-05_Biogasindustryfigures2017-2018_english.pdf (accessed on 13 May 2021).

60. Scarlat, N.; Dallemand, J.-F.; Fahl, F. Biogas: Developments and perspectives in Europe. Renew. Energy 2018, 129, 457-472. [CrossRef]

61. Kosewska, K.; Kamiński, J.R. Economic analysis of construction and operation of agricultural biogas plants in Poland. Agric. Eng. 2008, 1, 189-194.

62. Oniszk-Popławska, A.; Zownik, M.; Wiśniewski, G. Production and Use of Agricultural Biogas; EC BREC/IBMER: Gdansk, Poland, 2003; ISBN 83-86264-91-8.

63. Cucui, G.; Ionescu, C.A.; Goldbach, I.R.; Coman, M.D.; Marin, E.L.M. Quantifying the economic effects of biogas installations for organic waste from agro-industrial sector. Sustainability 2018, 10, 2582. [CrossRef]

64. Cherubini, F.; Strømman, A.H. Life cycle assessment of bioenergy systems: State of the art and future challenges. Bioresour. Technol. 2011, 102, 437-451. [CrossRef]

65. Deremince, B.; Königsberger, S. Biogas \& Biomethane Workshop on the Supply Potentials and Renewable Gases for TYNDP 2018. Available online: https:/ / www.entsog.eu/public/uploads/files/publications/Events/2017/tyndp/EBA_Biogas\%20and\%20 biomethane-final.pdf (accessed on 13 May 2021).

66. Biogas Plant Market-Growth, Trends, COVID-19 Impact, and Forecasts (2021-2026). Available online: https://www. researchandmarkets.com/reports/4997528/biogas-plant-market-growth-trends-covid-19\#rela2-1824151 (accessed on 3 October 2021).

67. USDA. Available online: https://portal.nifa.usda.gov/enterprise-search/project_details/ss/650 (accessed on 13 May 2021).

68. Benato, A.; Macor, A. Italian biogas plants: Trend, subsidies, cost, biogas composition and engine emissions. Energies 2019, $12,979$. [CrossRef]

69. Benato, A.; Macor, A. Biogas engine waste heat recovery using organic rankine cycle. Energies 2017, 10, 327. [CrossRef] 
70. Kwiecińska, A. Ecological Management of Slurry with the Use of Membrane Techniques; Department of Environmental Chemistry and Membrane Processes, Faculty of Environmental and Power Engineering, Silesian University of Technology: Gliwice, Poland, 2013.

71. IPPC Directive. Council Directive 96/61/EC Concerning Integrated Pollution Prevention and Control. 1996. Available online: https:/ / www.ecolex.org/details/legislation/council-directive-9661ec-concerning-integrated-pollution-prevention-andcontrol-lex-faoc034860/? (accessed on 1 November 2021).

72. HELCOM. 2020. Available online: http:/ / www.helcom.fi (accessed on 22 May 2020).

73. Gungor, K.; Karthikeyan, K.G. Probable phosphorus solid phases and their stability in anaerobically digested pig manure. Trans. ASAE 2005, 48, 1509-1520. [CrossRef]

74. Kutera, J. Slurry Management; Agricultural University Publishing House: Wrocław, Poland, 1994; p. 370.

75. Baltic Green Belt. Available online: http:/ / balticgreenbelt.org.pl (accessed on 30 September 2012).

76. Zbytek, Z.; Talarczyk, W. Slurry and Environmental Protection; Łukasiewicz Research Network Industrial Institute of Agricultural Engineering, Forest Horticulture Agricultural Technique Publishing: Poznan, Poland, 2008; Volume 4, pp. 12-14.

77. Jochimsen, H. Betriebszweigabrechnung für Biogasanlagen, Arbeiten der DLG, Bd.200; Velags DLG: Frankfurt, Germany, 2006.

78. Podkówka, Z. Biogas from slurry. In IX ECO- $€$ URO-ENERGY, Engineering of Renewable Energy Sources, Monograph; Mroziński, A., Ed.; Grafpol: Bydgoszcz, Poland, 2016; pp. 147-165. ISBN 978-83-64423-33-8.

79. Marszałek, M.; Banach, M.; Kowalski, Z. Manure utilization by methane and oxygen fermentation-Biogas and compost production. Tech. J. 2011, 10, 143-158.

80. Debska, B. Properties of Humic Substances in Soil Fertilized with Slurry. Ph.D. Thesis, University of Technology and Agriculture, Bydgoszcz, Poland, 2004.

81. Flizikowski, J.; Bieliński, K. Designing Environmental Energy Processes; ATR Publishing House: Bydgoszcz, Poland, 1999.

82. Wałowski, G. Development of biogas and biorafinery systems in Polish rural communities. J. Water Land Dev. 2021, 49, 156-168. [CrossRef]

83. Curkowski, A.; Onkisz-Popławska, A.; Mroczkowski, P.; Zowski, M.; Wiśniewski, G. A Guide for Investors Interested in Building Agricultural Biogas Plants; Ministry of Economy at the Institute for Renewable Energy: Warsaw, Poland, 2011. Available online: http:/ / www.mg.gov.pl/node/13229 (accessed on 4 October 2021).

84. Machała, R. Practical Management of the Company's Finances; Polish Scientific Publishers (PWN): Warsaw, Poland, 2001; ISBN 8301132299.

85. Rogowski, W. Calculus of Investment Efficiency; Wolters Kluwer: Alphen aan den Rijn, The Netherlands, 2013; ISBN 978-83-264-6016-6.

86. Szlachta, J. Analysis of the economic profitability of building straw-fired boiler houses and reduction of gas emissions during their use. Agric. Eng. 2005, 7, 331-338.

87. Kuczowic, J.; Kuczowic, K. Investment Decisions; Publishing House of the University of Economics in Katowice: Katowice, Poland, 2006; ISBN 83-7246-812-5.

88. Wskaźniki Efektywności Ekonomicznej Projektów. Available online: http://www.energia.eco.pl/EKONOM/ASPEKT/WSKAZ HTM (accessed on 4 October 2021).

89. Discounted Payback Period. Available online: https://corporatefinanceinstitute.com/resources/knowledge/finance/discountedpayback-period/ (accessed on 4 October 2021).

90. Profitability Index. Available online: https://www.investopedia.com/terms/p/profitability.asp (accessed on 4 October 2021).

91. Kozlova, M. Real option valuation in renewable energy literature: Research focus, trends and design. Renew. Sustain. Energy Rev. 2017, 80, 180-196. [CrossRef]

92. Menegaki, A. Valuation for renewable energy: A comparative review. Renew. Sustain. Energy Rev. 2008, 12, 2422-2437. [CrossRef]

93. Fernandes, B.; Cunha, J.; Ferreira, P. The use of real options approach in energy sector investments. Renew. Sustain. Energy Rev. 2011, 15, 4491-4497. [CrossRef]

94. Chang, C. A critical analysis of recent advances in the techniques for the evaluation of renewable energy projects. Int. J. Proj. Manag. 2013, 31, 1057-1067. [CrossRef]

95. Savolainen, J.; Collan, M.; Luukka, P. Analyzing operational real options in metal mining investments with a system dynamic model. Eng. Econ. 2017, 62, 54-72. [CrossRef]

96. Ceseña, M.E.A.; Mutale, J.; Rivas-Dávalos, F. Real options theory applied to electricity generation projects: A review. Renew. Sustain. Energy Rev. 2013, 19, 573-581. [CrossRef]

97. Santos, L.; Soares, I.; Mendes, C.; Ferreira, P. Real options versus traditional methods to assess renewable energy projects. Renew. Energy 2014, 68, 588-594. [CrossRef]

98. Boomsma, T.K.; Linnerud, K. Market and policy risk under different renewable electricity support schemes. Energy 2015, 89, 435-448. [CrossRef]

99. Kumbaroğlu, G.; Madlener, R.; Demirel, M. A real options evaluation model for the diffusion prospects of new renewable power generation technologies. Energy Econ. 2008, 30, 1882-1908. [CrossRef]

100. Martínez-Ceseña, E.A.; Mutale, J. Application of an advanced real options approach for renewable energy generation projects planning. Renew. Sustain. Energy Rev. 2011, 15, 2087-2094. [CrossRef]

101. Kim, B.; Lim, H.; Kim, H.; Hong, T. Determining the value of governmental subsidies for the installation of clean energy systems using real options. J. Constr. Eng. Manag. 2012, 138, 422-430. [CrossRef] 
102. Schmitz, M.; Madlener, R. Economic viability of kite-based wind energy powerships with CAES or hydrogen storage. Energy Procedia 2015, 75, 704-715. [CrossRef]

103. Bastian-Pinto, C.; Brandão, L.; Hahn, W.J. Flexibility as a source of value in the production of alternative fuels: The ethanol case. Energy Econ. 2009, 31, 411-422. [CrossRef]

104. Sheen, J. Real option analysis for renewable energy investment under uncertainty. Lect. Notes Electr. Eng. 2014, $293,283-289$.

105. Kozlova, M.; Collan, M.; Luukka, P. Comparison of the datar-mathews method and the fuzzy pay-off method through numerical results. Adv. Decis. Sci. 2016, 2016, 7836784. [CrossRef]

106. Heggedal, A.; Linnerud, K.; Fleten, S. Uncertain climate policy decisions and investment timing: Evidence from small hydropower plants. Energy 2014, 78, 154-164.

107. Fleten, S.; Molnár, P.; Nygård, M.T.; Linnerud, K. Green certificates and investments in small hydro power plants. In Proceedings of the 2016 13th International Conference on the European Energy Market (EEM), Porto, Portugal, 6-9 June 2016; pp. 1-6.

108. Kowalczyk-Juśko, A. Biogas Plants as an Opportunity for Agriculture and the Environment; Foundation for the Development of Polish Agriculture: Warsaw, Poland, 2013; ISBN 978-83-937363-0-0.

109. Igliński, B.; Buczkowski, R.; Iglińska, A.; Cichosz, M.; Piechota, G.; Kujawski, W. Agricultural biogas plants in Poland: Investment process, economical and environmental aspects, biogas potential. Renew. Sustain. Energy Rev. 2012, 16, 4890-4900. [CrossRef]

110. Walla, C.; Schneeberger, W. The optima size for biogas plants. Biomass Bioenergy 2008, 32, 551-557. [CrossRef]

111. Walczak, J. Investment costs for agricultural biogas plants and possibility of their funding. In Agricultural Biogas Plants; Walczak, J., Ed.; Publishing and Printing Team of the Institute of Animal: Cracow, Poland, 2010; pp. 39-52. (In Polish)

112. Kunikowski, G.; Rogulska, M. Economic Model of a Small Agricultural Biogas Plant; Nowa Energia: Adelaide, Australia, 2011; pp. 3236. Available online: https://nowa-energia.com.pl/media/magazyny_archiwalne/2011/magazyn_nowa_energia_2011_01.pdf (accessed on 30 September 2021).

113. Benjamin, M.F.D.; Tan, R.R.; Razon, L.F. Probabilistic multi-disruption risk analysis in bioenergy parks via physical input-output modeling and analytic hierarchy proces. Sustain. Prod. Consum. 2015, 1, 22-33. [CrossRef]

114. Pukšec, T.; Duić, N. Economic viability and geographic distribution of centralized biogas plants: Case study Croatia. Clean Technol. Environ. Policy 2012, 14, 427-433. Available online: https:/ /link.springer.com/article/10.1007/s10098-012-0460-y (accessed on 30 September 2021). [CrossRef]

115. Polish Academy of Sciences, Institute of Mineral and Energy Economy. Production and Use of Biogas in an Agricultural Biogas Plant on the Example of a Chicken Farm in Palowice; Polish Academy of Sciences: Cracow, Poland, 2005. Available online: https:/ / slaskie.pl/images/oze/sc_palowice.pdf (accessed on 30 September 2021).

116. Czekała, W.; Kaniewski, J. Prospects for the Development of Biogas Plants in Rural Areas of the Ślaskie Voivodeship; Academy of the Sun Krzysztof Frąszczak: Poznan, Poland, 2015; ISBN 978-83-944103-0-8.

117. Curkowski, A.; Onkisz-Popławska, A.; Wiśniewski, G.; Zowski, M. A Small Agricultural Biogas Plant with Local Management of Waste Heat and Digestate; Foundation Institute for Sustainable Development: Warsaw, Poland, 2011.

118. Doskočil, R.; Škapa, S.; Olšová, P. Success evaluation model for project management. Econ. Manag. 2016, 4, 167-185. [CrossRef]

119. Durana, P.; Michalkova, L.; Privara, A.; Marousek, J.; Tumpach, M. Does the life cycle affect earnings management and bankruptcy? Oeconomia Copernic. 2021, 12, 425-461. [CrossRef]

120. Faber, A. Potential and Consequences of Agricultural Biomass Production for Energy. 2008. Available online: http://www.cire. pl/pliki/2/potenc_konsekwenc_pdf (accessed on 15 June 2016).

121. Voytovych, I.; Malovanyy, M.; Zhuk, V.; Mukha, O. Facilities and problems of processing organic wastes by family-type biogas plants in Ukraine. J. Water Land Dev. 2020, 45, 185-189. 